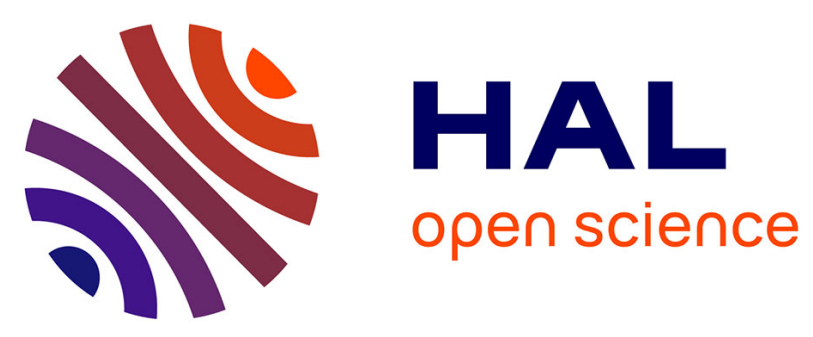

\title{
The Problem of the Ancient Name Java and the Role of Satyavarman in Southeast Asian International Relations Around the Turn of the Ninth Century CE
}

\author{
Arlo Griffiths
}

\section{- To cite this version: \\ Arlo Griffiths. The Problem of the Ancient Name Java and the Role of Satyavarman in Southeast Asian International Relations Around the Turn of the Ninth Century CE. Archipel, 2013, 85 (1), pp.43-81. 10.3406/arch.2013.4384 . hal-01958103}

\section{HAL Id: hal-01958103 \\ https://hal.science/hal-01958103}

Submitted on 17 Dec 2018

HAL is a multi-disciplinary open access archive for the deposit and dissemination of scientific research documents, whether they are published or not. The documents may come from teaching and research institutions in France or abroad, or from public or private research centers.
L'archive ouverte pluridisciplinaire HAL, est destinée au dépôt et à la diffusion de documents scientifiques de niveau recherche, publiés ou non, émanant des établissements d'enseignement et de recherche français ou étrangers, des laboratoires publics ou privés. 


\section{The Problem of the Ancient Name Java and the Role of} Satyavarman in Southeast Asian International Relations Around the Turn of the Ninth Century CE

\section{Arlo Griffiths}

\section{Citer ce document / Cite this document :}

Griffiths Arlo. The Problem of the Ancient Name Java and the Role of Satyavarman in Southeast Asian International Relations Around the Turn of the Ninth Century CE. In: Archipel, volume 85, 2013. pp. 43-81;

doi : https://doi.org/10.3406/arch.2013.4384

https://www.persee.fr/doc/arch_0044-8613_2013_num_85_1_4384

Fichier pdf généré le 31/08/2018 


\begin{abstract}
One of the most familiar narratives of ancient Southeast Asian history is the account of how Cambodian king Jayavarman II liberated his country from Javā, and consequently declared himself emperor in the year $802 \mathrm{CE}$. These events and this year are widely considered to represent the beginning of the Angkorian "empire". Recent years have seen several new scholarly contributions questioning parts of this narrative. One issue is the very historicity of the narrative elements about Jayavarman II, another topic of debate is the identity of Javā in the narratives related to Jayavarman II, and, more generally, in the history of Southeast Asia. After revealing the very weak foundations of certain recent attempts to argue that references to Javā in sources of the Southeast Asian mainland denoted a place on the continent or the Malay peninsula, this paper argues that the Khmer inscriptions refer to the island of Java when they use the term Javā. The paper shows, furthermore, that narratives involving Javā do not exclusively concern Jayavarman II, but that a certain Satyavarman is in some sources attributed a role very similar to that of the much more famous king Jayavarman II. It is proposed that this Satyavarman may well have been the king of that name who ruled in southern Campā around $800 \mathrm{CE}$, and hence that the epigraphical record of Satyavarman in Campā is likely to hold important clues not only for the history of Campā itself, but equally for international political relations between the Khmer, Cam and Javanese polities in the late 8th and early 9th century of our era.
\end{abstract}

\title{
Résumé
}

Le problème de l'ancien nom Java et du rôle de Satyavarman dans les relations internationales sud-est asiatiques vers le tournant du IXe siècle EC.

L'un des récits les plus connus de l'histoire ancienne de l'Asie du Sud-Est est celui racontant comment le roi Jayavarman II libére son pays de Javā et, par voie de conséquence, se proclame lui-même empereur en $802 \mathrm{EC}$. Ces événements et cette année sont généralement considérés comme représentant le début de «l'empire angkorien». Des contributions savantes parues ces dernières années ont remis en cause des éléments de ce récit. L'une des questions est celle de I'historicité des éléments narratifs concernant Jayavarman II, un autre élément du débat étant l'identité de Javā dans ces récits liés à Jayavarman II, et plus généralement dans l'histoire de l'Asie du Sud-Est. Après avoir mis en avant les fondations très fragiles de certaines tentatives récentes cherchant à démontrer que le Javā dans les sources d'Asie du Sud-Est continentale renvoie à un lieu sur le continent ou en péninsule malaise, cet article avance que les inscriptions khmères réfèrent à l'île de Java lorsqu'elles usent du terme Javā. Cet article montre, de plus, que les récits impliquant Javā ne concernent pas exclusivement Jayavarman II, mais que dans certaines sources un certain Satyavarman se voit attribuer un rôle très similaire à celui du roi beaucoup plus célèbre Jayavarman II. Nous proposons ici que ce Satyavarman pourrait bien être le roi du même nom ayant régné au Campā méridional vers $800 \mathrm{EC}$, et qu'ainsi les données épigraphiques relatives à Satyavarman au Campā contiennent vraisemblablement des indices importants, non seulement à propos de l'histoire du Campā lui-même, mais également à propos des relations politiques internationales entre les entités politiques khmère, cam et javanaise à la fin du VIIIle siècle et au début du IXe siècle de notre ère. 


\title{
The Problem of the Ancient Name Java and the Role of Satyavarman in Southeast Asian International Relations Around the Turn of the Ninth Century CE
}

\author{
«Tout revient donc en fin de compte \\ à une question de méthode.» \\ Louis-Charles Damais (1964: 94)
}

\section{Introduction}

One of the most familiar episodes of ancient Southeast Asian history is without doubt the account of how Cambodian king Jayavarman II returned from Javā, in order to liberate his country from it founded the "cult of the Devarāja", and consequently declared himself emperor (cakravartin) on Mount Mahendra in the year 724 Śaka, or $802 \mathrm{CE}$. These events and this year are widely considered to represent the beginning of the Angkorian "empire". Recent years have seen several new scholarly contributions questioning parts of this account.

One issue is the very historicity of the narrative elements about Jayavarman II, including those that involve Javā. It has been argued - to my mind persuasively - that there is every reason to read the sources recounting them as what they are: retrospective accounts of events in the past, whose historical veracity cannot be taken for granted, and which may reveal more about the period during which they were written than about the past they pretend to deal with. ${ }^{1}$

* I extend my thanks to Éric Bourdonneau, Dominic Goodall, Christian Lammerts, Amandine Lepoutre, Jan Wisseman Christie and Hiram Woodward for their aid during the process of writing this essay; to Pierre Pichard for drawing the map.

1. This is argued most explicitly and exhaustively in a forthcoming paper of Michael Vickery. Several of his earlier writings (e.g. 1992, 2001) already foreshadow the idea that 
Another topic of debate is the identity of Javā in such retrospective accounts, and, more generally, in the history of Southeast Asia. The contributions on this topic tend to be marked by a focus on particular groups of sources with their own particular consequences for the conclusions that are drawn with regard to the identity (or identities) of the land (or lands) that the Khmers in the $7^{\text {th }}$ through $13^{\text {th }}$ centuries of our era knew as Javā. Two studies were contributed by scholars with a primary interest and competence in comparative-historical linguistics, seeking to apply their expertise to problems of history (Mahdi 2008, Ferlus 2010). Both appear to be founded on the earnest conviction that it is possible, on the basis of a linguistic observation, to propose comprehensive solutions to intricate webs of interrelated problems that have occupied historians for over a century. One of them is among several contributions of scholars arguing that Javā was situated on the Southeast Asian mainland, and here we encounter the unspoken assumption that it is sufficient to demonstrate that a toponym Javā has been in use in particular places or a particular place on the Southeast Asian mainland at some point in history, to conclude that that particular Javā was meant in the Khmer inscriptions (all of them), and not the island of Java. Indeed, more generally, we encounter time and again a flagrant failure to comply with fundamental requirements of historiographic method, such as a weighing of evidence based on a consideration of the epistemological hierarchy of sources, and giving account of all relevant sources of evidence. ${ }^{2}$ The plethora of tendentious arguments, based on partial presentations or simply incomplete awareness of the relevant evidence, is in need of a corrective, for we already see colleagues giving silent approval to one or the other of these arguments, or declining to express any judgment on the relative persuasiveness of different proposals on the identity of Javā. ${ }^{3}$ Although the specialization of areal and disciplinary expertise has advanced so much that it is no longer possible for any single scholar honestly to pretend to have digested all of the relevant primary and secondary sources, I have made an effort to read widely, and the presentation of my findings on the problem of the ancient name Java forms the bulk of this paper.

\footnotetext{
this narrative is an $11^{\text {th }}$-century legend. Vickery cites the important observation of George Cœdès (1937-66, vol. VII, p. 129): «Pour l'épigraphie angkorienne qui commence en fait avec le règne d'Indravarman en 877, ceux de Jayavarman II et de son fils dont on n'a pas encore trouvé d'inscription constituent une époque semi-légendaire, à laquelle les grandes familles religieuses font remonter l'origine de leur sacerdoce, et les propriétaires de biens fonciers l'origine de leurs titres de propriétés ». See now also Bourdonneau (2011a: 100-101 with the references in $\mathrm{n} .18)$ and $(2011 \mathrm{~b}: 1345,1359)$.

2. For a nuanced discussion of the problem of hierarchization of sources in early Southeast Asian history, particularly the history of ancient Cambodia, I refer to Bourdonneau (2003).

3. See e.g. Laffan (2009: 20-28); Sharrock (2009: 218); Woodward (2011: 93 and 94).
} 


\section{The Narratives of Jayavarman II and Related Accounts of the Khmer Past}

As background to the discussion that will follow, I must first present the two epigraphical passages which recount Jayavarman's actions with regard to Javā, immediately adding to them two other narrative passages which are clearly related to each other and together related to the Javā narrative.

Inscription of Sdok Kak Thom: K. 235, face C, lines 61-62 and lines 69-744 man vrah pāda parameśvara mok 'aṃvi javā pi kurun ni 'nau nagara indrapura. steñ 'añ śivakaivalya ta 'ji prājñ̄a jā guru jā răjapurohita ta vraḥ pāda parameśvara. man vraḥ pāda parameśvara thlen mok 'amvi 'indrapura sten் 'añ śivakaivalya mok nu vrah kandvāra homa nā vrah rājakāryya [...] man vraḥ pāda parameśvara dau kurun ni 'āy mahendraparvvata. sten 'añ śivakaivalya dau 'angvay ta nagara noh 'ukk paṃre ta vrạ̣ pāda parameśvara rūva noḥh 'nau man vrāhmaṇa jmạ hiranyadāma prājñā siddhividyā mok 'amvi janapada. pi vrah pāda parameśvara 'añjeñ thve vidhi leha len kam pi kamvujadeśa neh 'āyatta ta javā ley. len 'āc ti kamraten phdai karoṃ mvāy guh ta jā cakravartti. vrāhmaṇa noḥ thve vidhi toy vrah toy vrah vināśikha. pratișțā kamraten jagat ta rāja.

'When H.M. Parameśvara (i.e. Jayavarman II) ${ }^{5}$ came from Java to rule and hold sway in the royal city of Indrapura, the sten 'añ Sivakaivalya, the learned patriarch, served as spiritual preceptor. When H.M. Parameśvara rose up and came from Indrapura, the ster 'añ Sivakaivalya came as member of the holy College of Sacrifices assigned to the holy Royal Service. [...] When H.M. Parameśvara went forth to rule and hold sway in Mahendraparvata, the sten 'añ Sivakaivalya went [and] settled in that royal city as well, continuing to serve H.M. Parameśvara as before. When the brähmaṇa named Hiranyadāman, who was learned in knowledge of siddhi, came from Janapada - because H.M. Parameśvara had invited [him] to perform a sublime rite which would let this Kamvujadeśa not be subject to Java any longer [and] would let and allow only one High Lord of the Earth to serve as cakravartin, - that brähmana performed a rite according to the Vināsikha [and] set up the Sovereign High Lord of the World (i.e. the Devarāja of the Sanskrit text). ${ }^{6}$

\section{Inscription of Vat Samron: K. 956, lines 14-17}

man vrah pāda stac dau parameśvara stac 'āy rodval pandval ta mratāñ śrī prathivinarendra pre thve kālyanasiddhi leñ vvaṃ 'aṃpān vrah kaṃvujadeśa pi javā cāp ley 'oy vrạ̣ dākșinā bhūmi sratāc ròdval nu sarvvadravya 'val ta mratāñ śrī prathivinarendra

4. The "K." and "C." numbers cited in this paper refer to the EFEO inventories of the inscriptions of Cambodia and those of Campā, on which, see Cœdès 1937-66, vol. VIII; Cœdès, "Liste générale des inscriptions du Champa et du Cambodge " in Cœdès \& Parmentier 1923, pp. 1-37; Gerschheimer 2003-04; and Griffiths et al. 2012a. For Indonesian inscriptions, I follow in most cases the system of nomenclature introduced by L.Ch. Damais (see Damais 1952 and Damais 1970: 37-54). Since all epigraphical sources drawn upon here use the Śaka era, I favor in principle the use of this era when citing dates; readers not comfortable with this reckoning may mentally add 78 to each Śaka-year to approximate the corresponding year of the common era. As much as possible, I cite texts of inscriptions based on my own readings, applying a uniform system of transliteration to all epigraphical corpora treated here, except that (only in the case of Old Javanese texts) the sign $\circ$ is used to indicate independent (akșara) vowels, whereas the glottal stop of Mon and Khmer, expressed by the independent vowel signs, is marked with '. My use of the sign - indicates virāma/paten.

5. On this use of a posthumous name, see Jacques (2001).

6. Text and translation follow almost without modification those offered by Sak-Humphry \& Jenner (2005: 96-104). 
'When his majesty who had gone to Parameśvara (i.e. Jayavarman II) was pleased to reside at Rdval, he deputed Mratāñ Śrī Prthivīnarendra to order to carry out an auspicious stratagem (kalyānasiddhi) to end Java's continuing to hold the sacred Kamvujadeśa, he gave as holy fee the fields of Sratāc and Rdval, with all their property, to Mratāñ Śrī Prthivīnarendra.' 7

The first of these passages has been known to scholarship for more than a century and forms the basis of the Javā narrative associated with Jayavarman II found in all works on ancient Southeast Asian history. ${ }^{8}$ The second was published about fifty years ago, and despite obvious differences its account was not at that time felt to be in sufficient disagreement with that of the first to require revision of the Javā narrative. It is only due to the discovery in the 1980s of an important bilingual Sanskrit/Khmer inscription, of 988 Saka or thereabouts, that important new light can and must now be cast on the accounts contained in K. 235 and K. 956. The inscription in question, K. 1158, was recovered from Sab Bak in Nakhon Ratchasima province, Thailand, but it has been suggested that it is not quite certain that this is also where the inscription was originally erected. ${ }^{9}$ Even before it was published by Chirapat Prapandavidya (1990), it attracted interest from scholars, and publications discussing its significance in greater or lesser details have multiplied since then. ${ }^{10}$

Part of the interest of this inscription, and of the question where it might originally have been erected, lies in the fact that it mentions in its Khmer part a piece of historical information that is strikingly reminiscent of an event recorded in another inscription, K. 111, recovered rather far away from Nakhon Ratchasima, namely at Vat Sithor, a site about halfway between Phnom Penh and Kompong Cham. This Vat Sithor inscription dates from about a century earlier, from the reign of Jayavarman III that started in 890 Śaka, and states the following: ${ }^{11}$

7. Text cited after Cœdès 1937-66, vol. VII, p. 130. Translation partly taken from Jenner (2009b: 509).

8. See Cœdès \& Dupont (1943-46: 57) : «L'inscription de Sdǒk Kăk Thom a déjà été publiée deux fois : Aymonier, dès 1901, en a résumé et traduit partiellement la version khmère, accompagnant ce travail d'une analyse de la paraphrase sanskrite due à A. Barth. Louis Finot, en 1915, a donné édition et traduction complètes des deux textes.»

9. Jacques wrote (2005: 24 n. 29): «la stèle, petite, peut avoir été apportée d'on ne sait où au Cambodge». Vickery (forthcoming) affirms that there is no reason to be skeptical about the provenance, and furnishes a reason to think the stela may originate in the area where it was found.

10. Cf., i.a., Ang Chouléan (1998: 119-120); Sundberg (2003: 178 n. 28); Skilling (2004: 157); Jacques (2005: 24); Woodward (2005: 146). Michael Vickery discusses it too in his forthcoming paper, and Julia Estève has discussed it at some length in her unpublished doctoral dissertation.

11. Vat Sithor Inscription (K. 111; Cœdès 1937-66, vol. VI, p. 195; after 890 Śaka), st. XLV and XLIX. 


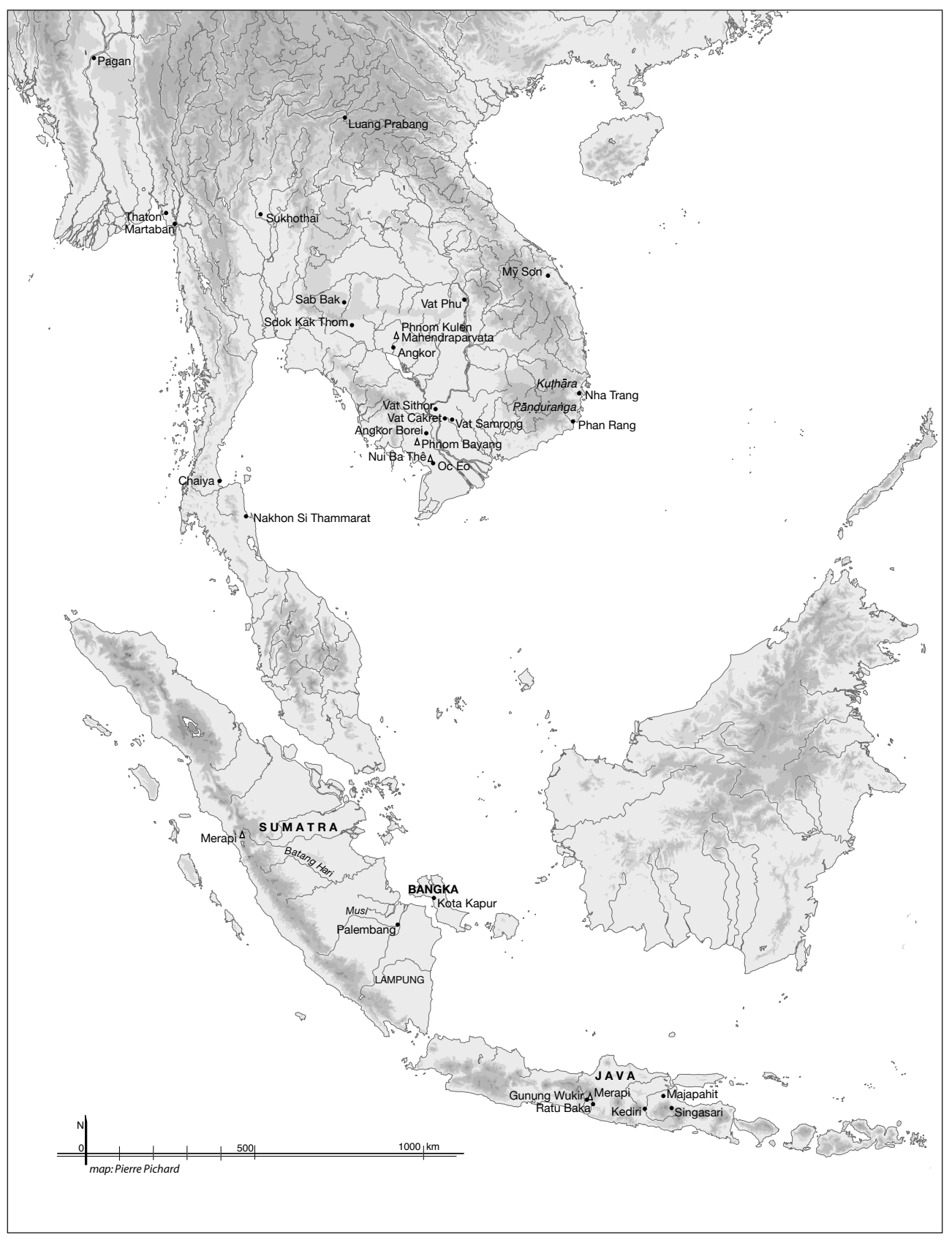


śrīsatyavarmmanā bajrilokeśārccā daśādhikāḥ

sthāpitāḥ prāg girau bhagnāsanā yo tișthipat punạ̣ \||

$\simeq$ - rmmapațtane grāme svaparārthaprasiddhaye

$\simeq \simeq$ dīn sthāpayām āsa navașaṇmañgale śaka $\|$

Glossing over a few problems of interpretation, ${ }^{12}$ I propose that these two stanzas might mean:

'He [Kirtipandita, the subject of the inscription] re-installed the ten excellent images of Vajrilokeśa that had been installed formerly on the mountain by Srī Satyavarman, and whose thrones had been broken.

In the settlement ..rmapattana he installed ... etc. in the course of 869 Śaka, for the realization of both his own benefit and that of others.'

It seems to have been Claude Jacques (1992: 3-4) who first pointed out that this must be related to the events recorded in the inscription recovered from Thailand, for there we read: ${ }^{13}$

aștāșțaraṇdhre sitasaptaśukre tapasyamāse sugatādikārccāḥ

teñā̄snage bhāgyaviśeșatîrthe sa vraḥdhanus sūrir atișthipad yạ \|

'It was he, the learned Vrạ Dhanus, who in 988 Śaka, on Friday the seventh of the bright fortnight of the month Tapasya (= Phālguna), erected the images of the Buddha etc. on the Teñ Pās mountain, place of pilgrimage capable of yielding extraordinary fortune.'

ri vraḥ vuddhalokeśvara ${ }^{14}$ ta pram pvānna ti kaṃsten · śrī satyavarma ta mān siddhi sthāpanā vren' le 'abhayagiri tem kaṃ pi javāa 'ākrānta sruk· khmera • vrah noḥ syan ta nu tvalla dau hon' • kamraten 'añ · ta guru dharanīndrapura jirnoddharana thve pi pravai sthāpanā 'issa vrah noh vin ta tel- noḥ syań ta 'yat ' vighna • ri 'ācāryya vrạ dhanu ta śișya gi ta sthāpanā vraḥ neh 'āy ta 'așta 'așța nava ta gi rājya vraḥ pāda kạ̣mraten'. kaṃtvan. 'añ ' śrī 'udayādityavarmmadeva •

'As for the nine Buddhalokeśvaras, they were formerly established atop the Abhayagiri by Srī Satyavarman, who possessed supernatural power (siddhi), in order that Javā would not attack the Khmer domain. Those deities had fallen to pieces. K.A. the Guru of Dharanīndrapura has organized repair. He has made embellishments. He has newly installed all those deities. As before, those [deities] became free of obstacles. As for Ācārya Vrah Dhanu, his pupil, he has established these deities in 988 [Śaka] during the reign of His Majesty of the matriline Śrī Udayādityavarmadeva.'

Let me sum up what we gather from the comparison of these two inscriptions. A certain Satyavarman is credited with the establishment of Buddhist images on top of a mountain at an unspecified time. The Sab Bak

12. Mainly the number of images installed (daśādhikāh can and has been interpreted to mean 'more than ten') and the identity of these images. Cœdès interpreted "images de Vajrin et de Lokeśa", but comparison with the Sab Bak inscription rather suggests that Vajrilokeśa is a synonym of Buddhalokeśvara, on which, see note 14.

13. Sab Bak Inscription, K. 1158; ed. Chirapat Prapandavidya 1990; unpublished improved edition by Julia Estève and Gerdi Gerschheimer. Sanskrit: St. XIII; Khmer: lines 31-36 (both face A).

14. For a suggestion regarding the identity of these Buddhalokeśvaras, see Woodward (2005: 146); cf. also Woodward (1994-95: 108). It should be noted that this specific name is attested in at least two inscriptions of Campā (C. 92 and C. 213). 
inscription specifies that the mountain where this original foundation took place was called Abhayagiri, that is 'Mountain of Safety', and that the purpose of the foundation was to protect sruk khmer, that is the Khmer domain, from Javā. The Vat Sithor inscription credits the Buddhist scholar Kìrtipaṇdita with a restoration of these images, that had apparently suffered the ravages of time, in or around 869 Saka. ${ }^{15}$ The Sab Bak inscription credits an unnamed Guru of Dharanīndrapura with similar restoration activities at an unspecified point of time. It adds that his pupil Vrah Dhanus erected several Buddhist images on a mountain called Ten Pās ${ }^{16}$ in the year 988 Śaka. In other words, his master, the Guru of Dharanīndrapura, must have lived before that year, and it is not evident that Vrah Dhanus' foundation is geographically or otherwise related to that of Satyavarman.

The parallels with the legend recorded about Jayavarman II in the oftcited inscriptions of Sdok Kak Thom and Vat Samron (K. 235 and K. 956), involving his use of siddhi in defense against Javā, are too striking to be coincidental, but nobody has so far commented on the discrepancy between the attribution to Jayavarman II in the case of K. 235 and K. 956 as against the name Satyavarman in K. 111 and K. 1158. What I want to do in what follows is to explore the possibility of identifying the Satyavarman figuring in these Khmer inscriptions with the king of the same name occurring in the epigraphy of Campā, while simultaneously identifying Javā with the island of Java, more specifically with the kingdom of central Java associated with the Śailendra dynasty, ${ }^{17}$ and to consider the implications of such a combined hypothesis. In the process, I will review three recent publications addressed from various perspectives to the issue of Java.

\section{Can the Javā of the Khmer inscriptions be identified as the island of Java?}

The ancient name of the island Java, and its identifiability with various similar-sounding names known from ancient Southeast Asian, Chinese and Arab sources, is an old problem, compounded by the fact that similarsounding and obviously related names in some modern mainland Southeast Asian languages refer not to the Javanese or to Java in particular, but to Malays or the Malay world in general, ${ }^{18}$ or to localities in northern Laos. The paper "Localisation, identité et origine du Javā de Jayavarman II", by

15. See on this inscription and the scholar Kïrtipaṇita the articles by Mertens (2000) and Sharrock (2009).

16. This means something like 'Lady of the creepers'. It is not a Khmer version of Abhayagiri. 17. It is not very important for my argument that I presume, with most other current scholars, that former notions of parallel existence of two lines of rulers in $8^{\text {th }}-9^{\text {th }}$ century Java, must be abandoned in favor of a 'single dynasty' model. See Sundberg 2009 for the state of the field.

18. See Laffan (2009), the contribution of Claudine Salmon to this issue, and the citation of Pierre Dupont in $\mathrm{n} .78$ below. 
Michel Ferlus aims to demonstrate that the term java in those Khmer inscriptions which recount the story of Jayavarman II can be explained as a word originally meaning 'mountain', hence also 'artificial mound', and would in the latter sense have been applied by other peoples to the Khmers, and through Khmer expansion to what is now northern Laos have become associated with that part of mainland Southeast Asia. ${ }^{19}$ Throughout, Ferlus is convinced but makes no effort to demonstrate that "le vocable java de l'inscription de Sdok Kak Thoṃ ne peut en aucun cas désigner l'île de Java" (2010: 8). This statement was meant to hold for the inscription of Vat Samron as well, and by implication also for that of Sab Bak, which Ferlus was certainly unaware of and hence ignored altogether. His complicated argument is marked at several steps by the methodological flaw of accepting a given interpretation that seems possible, without asking whether other interpretations might also be possible, and then doing the countercheck of weighing the likeliness of his interpretation against others. ${ }^{20}$ I think that three examples will be sufficient to demonstrate that Ferlus' argument rests on very weak foundations.

First, Ferlus' entire argument relies on the hypothesis that the Chinese designation Funan of the ancient polity associated with such sites as Óc Eo and Angkor Borei reflects the Old Khmer word vnam meaning 'mountain'.

19. Ferlus takes his inspiration from the work of Tatsuo Hoshino, to whom he even dedicates his article (just as Hoshino had dedicated his 2002 article to Ferlus). Ferlus (2010: 68) admits: «dans l'ensemble, les spécialistes n'admettent pas l'identification avec le Java indonésien, mais aucun ne va jusqu'à admettre les idées novatrices de Tatsuo Hoshino qui sont parfois même rejetées avec vigueur ». With regard to the latter point, I have nowhere found a vigorous rejection of Hoshino's work, but only scattered negative remarks showing that his work is indeed very controversial. Vickery (1998: 81 n. 60) affirms: "I must add here that in general I do not accept many of Hoshino's presuppositions and methods using Southeast Asian historical documents. On certain isolated points, however, he has contributed valuable new insights." Jacques (2005: 24) specifies: "Sa démonstration toutefois n'est guère convaincante. Il explique en particulier que Jayavarman II, venant de Javā, arrivait au Laos: mais pourquoi dans ces conditions ce roi aurait-il commencé sa conquête du pays khmer par les provinces les plus méridionales? Il confond souvent d'autre part Yava avec Java, voire avec Yavana.» Woodward (2011: 87) mentions "tendentious aspects of Hoshino's article".

20. This same objection was raised against another recent contribution of Ferlus to tackling an old problem of early Southeast Asian history by Bourdonneau (2007: 132, n. 50, my emphasis): "Michel Ferlus propose de restituer derrière le titre fan, porté par les premiers souverains du Funan selon les textes chinois, le sanskrit brahma ou brāhmaṇa. L'hypothèse avait déjà été envisagée par Pelliot sans grande conviction. Ferlus y revient avec une argumentation de phonétique historique : antérieure à l'effacement de la médiale -r- aux alentours $\mathrm{du} \mathrm{IV}^{\mathrm{e}}$ siècle, le caractère fan permettait de transcrire tout à fait correctement le sanskrit brahma/brāhmaṇa (Ferlus 2005 : 4-5). Que le terme brahmane ait pu ainsi entrer dans la titulature des premiers rois du Funan soulève de nombreuses interrogations. Mais c'est la démarche en soi qui nous semble d'abord faire difficulté. Que le caractère fan transcrive de façon satisfaisante les [mots] brahma/brāhmana ne nous dit rien sur les autres correspondances éventuelles avec des termes en vieux khmer et les raisons pour lesquelles il faudrait alors privilégier l'hypothèse de Ferlus.» 
This is, however, not more than a possibility, and one that is treated with much circumspection by more than one historian. ${ }^{21}$ Ferlus for his part treats this hypothesis as an established fact (2010: 69):

\begin{abstract}
C'est vraisemblablement dans le sens de «monticule, tertre artificiel (lieu de cérémonies)» plus que celui de «temple» et encore moins de "montagne» qu'il faut chercher la justification du nom «Funan» que les Chinois, frappés par des pratiques qu'ils ne connaissaient pas, ont donné au Cambodge des premiers siècles de notre ère. Cette signification nous accompagnera tout au long de ce texte dans notre quête sur l'identification du terme Javā.
\end{abstract}

The presumed meaning 'artificial mound' then becomes the basis for an indeed long-drawn web of ingenious and often far-fetched reasoning, but we see here the shakiness of its very starting point: the assumption that the designation Funan derives from the Khmer word for 'mountain' and the associated belief that there are no 'mountains' in Funan. It is impossible to follow Ferlus even in his point regarding the landscape, for there would have been nothing surprising if the various natural elevations, such as the Nui Ba Thê which dominates Óc Eo, the massif of seven mountains slightly further north, not to mention the Phnom Bayang, the Phnom Angkor Borei, etc., which so clearly mark the landscape of Funan, had attracted attention both from the ancient Funanese and from the contemporary Chinese precisely for what they are, and what they are still called in modern Khmer: bhnam (phnom), 'mountains'.

Second, Ferlus accepts without question the hypothesis recorded in H.L. Shorto's Dictionary of the Mon Inscriptions (1971: 117) that the word ja'ba' occurring in a single $11^{\text {th }}$-century Old Mon inscription from Thaton, a site on the coast facing the Bay of Bengal, denotes a "native of the region of northern Laos". Ferlus takes the dictionary definition at face value, and has not bothered to retrace its source. This source is probably the work of G.H. Luce (1969-70, vol. I: 24-25), who reported that "[i]n line 23 of the main section the words lwa' krom ja'ba are legible at the end of the line, but the context is obscure. $L w a$ ' is the tribal term Lawa or Wa, present in the name of the city, Lavapura (Lăvo, Lopburi). Krom is the Mon word, the western word for Cambojan (Old Burm. Krwaim; Thai Khôm). Ja'ba might be the Möan் Javā of Rāma Gāmì̀n's inscription (1292 A.D.), i.e. Luang Phra Bang'. On this basis, the sequence lwa' krom ja 'ba', about whose context we know nothing, is translated by Shorto as 'Lawas, Cambodians, and Laotians', and this interpretation is supported with a reference to "Lao $s w \bar{a}$ $(<* j v \bar{a})$, popular name of Luang Prabang". ${ }^{22}$ It is important to note how the

21. See e.g. the relevant work of Michael Vickery (1998: 33, 36 [with reference to Claude Jacques as expressing doubt about the hypothesis] and $421 \mathrm{n}$. 1; 2003-04: 125-126).

22. There is a small difference between Luce's reading ja 'ba and Shorto's ja 'ba', but perhaps 
circumspection of historian Luce has got lost in the representation of his hypothesis by linguist Shorto, so that the mere suggestion that the word denote 'Laotians' becomes an established fact for Ferlus. Against Luce's suggestion we may raise the objection - given the circumstance that contemporary inscriptions of Java consistently mention side-by-side the ethnonyms campa 'Cam', kmir 'Cambodian (i.e. Khmer)' and rəmən 'Mon' in lists of resident foreign traders ${ }^{23}$ — that one may justifiably expect Mon inscriptions of the same period, and all the more so inscriptions from coastal sites likely to have been frequented by overseas traders, to mention the Javanese. Before further philological evidence is adduced to exclude the possibility that this Old Mon word meant 'Javanese', it is inadmissible to use the word as evidence in an argument that Old Khmer java meant anything else.

Third, the claim (2010: 70) that Old Mon ja'ba' and Old Khmer javā, which Ferlus postulates originally to have denoted certain Khmers or the Khmers in general, «devaient avoir le sens premier de 'tertre, monticule', comme bhnam et fúnan» rests solely on the existence of phonetically similar words meaning 'mountain' in certain Aslian languages of the Malay peninsula. The Aslian languages belong, like Mon and Khmer, to the Austroasiatic family of languages, but are not closely related to either Mon or Khmer within that family, and the oldest data on these languages are about a millennium younger than the relevant data from Mon and Khmer. Ferlus demonstrates methodically how in terms of historical phonology Old Mon ja 'ba' and Old Khmer javā can be reconstructed to Proto-Mon-Khmer * əə6a?. He does not, however, ask the question whether the fact that the words can be reconstructed to a common ancestor also means that they have to be shared inheritance from the proto-language. In any case, his careful procedure as historical phonologist stands in stark contrast to his simple declaration — as he himself admits: «contre toute attente» — that the meaning of this inherited word can be determined on the basis of the Aslian data. Ferlus says nothing about whether the sound correspondences between

this difference is inconsequential (see Shorto 1971: xv). All the readable parts of the inscription were published by Khyac Sinh [Chit Thein] (1965), inscription nr. 1, who reads [lva' krom·] (ja') [ba]'.

23. See below, p. 68. As an aside, I wish to question also Ferlus' apodictic statement as to the modern Cam word kur denoting the Khmers: "Contrairement à une idée courante, ce terme n'a rien à voir avec les attestations de kvir et kmir des inscriptions chames ». Ferlus does not state which scholars have expressed this idea, but epigraphical evidence (part of which has only become available after Ferlus wrote) seems to show an internal development kmir-kvirkur in the course of the history of the Cam language, and may be adduced against Ferlus' claim. The form kmir is attested in Cam inscriptions of the $11^{\text {th }}$ century (C. 64, Griffiths et al. 2012b: 219-224) and the 12 ${ }^{\text {th }}$ (C. 17, Aymonier 1891: 40); kvir is found in inscriptions of the $13^{\text {th }}$ century, and $k u r$ is found in one of the $15^{\text {th }}$. See for examples of kvir and kur the entries on p. 67 below. 
the Aslian words and those in Mon and Khmer obey regular patterns or not, and hence it is unclear whether he is thinking of inherited Austroasiatic vocabulary, or whether he perceives the phonetic similarity between the various words as due to some loan scenario. Again, no other possibilities, such as coincidental phonetic similarity with the Mon and the Khmer words, or an etymological connectedness (whether through inheritance or borrowing) without preservation of semantic correspondence, are considered at all.

In short, the flaws of Ferlus' reasoning are so fundamental that his argument in favor of connecting java in the Old Khmer inscriptions with a polity in what is now northern Laos need not detain us any longer. This does not yet mean that the hypothesis itself is disproven. And indeed I do not pretend that in matters such as these, anything such as final proof will ever be forthcoming. We are limited to proposing hypotheses and counterhypotheses, and to weighing their respective power of persuasion. It is an incontrovertible fact that the inscription of Ram Khamhaeng of $1292 \mathrm{CE}$ (face IV, line 26) mentions a möan் javā ('principality of Javā') and situates it far to the north of Sukhothai; ${ }^{24}$ it is likewise an incontrovertible fact that a name spelled javā is associated with the Luang Prabang area of northern Laos till this day. These facts lay at the basis of the argument offered by Tatsuo Hoshino and, after him, by Michel Ferlus, and they determine the way these scholars select and read other sources. ${ }^{25}$ The historian's task is to weigh the possibility that it was this Javā that was intended in the Old Khmer inscriptions, against alternative possibilities, among which the possibility that the Old Khmer word denoted the island of Java; mutatis mutandis, the same possibilities must be weighed independently for any words that might be related, such as Old Mon ja 'ba'.

I limit myself here to the observation that Hoshino and Ferlus can rely on not a single local source from Northern Laos that is even remotely proximate in time to the Khmer inscriptions that associate Javā with Jayavarman II, let alone to the supposed events around $800 \mathrm{CE}$ associated with Javā in Jayavarman II's career. In what follows, I intend to show that, by contrast, there is a mass of Southeast Asian epigraphical data, relevant to the problem of Javā, and contemporary with the events reported retrospectively in those Khmer inscriptions or with those retrospective inscriptions themselves. It is

24. See Cœdès $(1924: 43,48)$ and Griswold \& Prasert ṇa Nagara (1971: 202, 220).

25. For the former scholar's arguments, see Hoshino (1986: 34-46); the same ideas are repeated, without scholarly apparatus, in Hoshino (2002). Hoshino shows no awareness of the fact that the Ram Khamhaeng inscription is controversial, and may not constitute evidence for the existence of a toponym Javā in the Luang Prabang area in 1292 CE. Ferlus is aware of this fact, but preempts criticism of the fact that his theory is essentially based on this inscription by his characterization of the controversy as «stérile» (2010: 67, n. 4). On the productiveness of the Ram Khamhaeng controversy, see now Terwiel (2011). 
my contention that these epigraphical data, and related data from later centuries, can be explained most parsimoniously if one assumes (a) that authors of Southeast Asian inscriptions meant with java the same thing that was meant when they used the term yavadvipa; (b) that Khmer authors used these terms with the same intended referent as did authors of inscriptions of Campā and of the Indonesian archipelago when using those terms; and (c) that in these three major epigraphic traditions of Southeast Asia, the intended referent of those terms remains stable throughout the epigraphic period. To this end, I will now proceed to present the evidence from these three traditions, and show that among them, it is only in Javanese inscriptions that the terms are intended as endonyms, while for the Khmers and Cams they referred to foreigners or a foreign land.

The first corollary of these observations is that the intended referent everywhere in this set of data was the island of Java (or a part of it); the second is that, when in other — in most cases later — Southeast Asian or foreign records, the term javā or foreign notations assumed to correspond to such a name denote something else than the island of Java, we are dealing with a parallel set of data, possibly reflecting more recent developments, whose interpretation must be accommodated historiographically next to, rather than in place of, the mass of epigraphic data. ${ }^{26}$

\section{Yava and Java in inscriptions of insular Southeast Asia}

A voluminous and learned study "reconstructing the history of Yavadvipa $[$ sic]" was published by Waruno Mahdi just a few years ago in the pages of this journal. Its argument is based on the ideas that the name Yavadvipa would have applied to a polity in the Batang Hari river basin on Sumatra, before migrating to the island of Java, ${ }^{27}$ and that the fact that there is a great volcano named Merapi on both islands is evidence of migration of toponyms that would have accompanied political migration. Although these ideas are of no direct consequence for my argument in this paper, Madhi's study does directly concern the terms that are central in my discussion, and hence cannot be left unmentioned. The line of reasoning adopted by its author is complex, and in my view methodologically unsound. Based as it is on an argument that is hard to unravel, this contribution is liable to mislead even specialist readers. A short discussion of this 2008 article by Waruno Madhi will therefore serve as introduction to the history of the toponyms Yavadvipa and Java in insular Southeast Asia.

26. Thus for instance the term jāvaka to denote the Malay Peninsula in the Sinhalese chronicle Cülavamsa, dealing with the $13^{\text {th }}$ century (cf. Jacques 2005: 21-22).

27. This is not a novel idea. For similar ideas, see Krom (1931: 83 and 99), and Moens as reported by Stutterheim (1939: 84 n. 1). 
With inevitable simplification, it seems fair to say that Mahdi engages too freely in associating facts that are not clearly connected, to build complicated historical revisionism on the assumption of connections that remain unproven; that he feels too little constrained by the results of preceding scholars and hence proposes radically novel hypotheses without addressing the question why existing communes opiniones would be wrong; that his revisionism is in fact based on an incomplete knowledge of the relevant primary and secondary sources, and an insufficient awareness of the risks of interpreting Sanskrit sources without being familiar with the clichés of Sanskrit literature; and that he cherry-picks from the sources he uses, ignoring elements which do not fit into the "unitary picture" that he aims to present (pp. 112, 136). I must limit myself to illustrating these flaws with just a few examples.

Firstly, the author rightly observes that foreign - Arabic, Chinese and Greek - sources often seem to situate places with names resembling Java or Yavadvippa not where we would prima facie expect them, namely in the place of the island of Java, but rather in or around the island of Sumatra. In particular, he retains from his previously published work the conclusion, with regard to "the Chinese pilgrim Faxian's itinerary of his 413-414 CE voyage from Sri Lanka via Yavadvipa (Yépótí 耶婆提, EMC *jia-ba-dej) to Guangzhou", that "the most likely location of Yavadvipa would be on the east coast of Sumatra", and that this "practically places it in the Batang Hari basin, the location of historical Malayu and Jambi" (p. 112). ${ }^{28}$ Although he is aware of the work of Michael Laffan (2009, cited in the form of its working paper version dating to 2005), he does not consider the possibility that the foreign sources in question may be in error (cf. Damais 1964: 95), or may be using toponyms in a less discrete manner than we are used to do today. In this way the question "Why the name came to refer to the island of Java" (sic!) can become the dominant thread of the article, whereas the preIslamic indigenous sources — presented below — unequivocally associate the name with the island of Java, so that the historian should rather ask how the name could ever have come to be applied to any other locality. ${ }^{29}$

Second, although the author rightly observes that it is strange to find the apparently Malay (or Batak) name Merapi applied to the important volcano

28. Although based on a different argument and a different reconstruction of Faxian's route, the seminal study of Max Deeg (2005: 179-185), which Mahdi ignores, arrives at a similar location for Yépótí. Excavations at the extensive and ancient Buddhist complex of Batujaya over the last decade (cf. Manguin \& Agustijanto Indrajaya 2011), whose results were published internationally too late to come to Deeg's attention, can be considered to have weakened the argument against identifying Yêpótí in West Java to the extent that it is based on the belief that there was no substantial Buddhist presence there in the $5^{\text {th }}$ century (Deeg 2005: 183, n. 894).

29. This is what Michael Laffan has done in his contribution of 2009. 
at the heart of Java, he ignores the fact that the pre-modern sources are not unanimous in naming it Merapi: while the majority of epigraphical and manuscript sources do refer to it by the name Marapi, some manuscript sources call the mountain Mandaragni, which suggests (because agni is a synonym of $a p i$ ) that, at least in popular etymology, the element mar- was associated with the mythical mountain Mandara, rather than with any Malay/Batak prefix. More significantly, the only pre-Islamic indigenous source known to me that seems to refer to the Merapi in West Sumatra is an Old Malay inscription from around the time of A dityavarman, which names it not Marapi but Mahāmeru. ${ }^{30}$ At least insofar as the extant historical sources have any say in the matter, there is no support for the author's assumption that "the name Merapi (originally perhaps [sic] Marapi) must have been first coined in Sumatra, and the volcano that originally carried that name probably was the one on that same island". Mahdi seems not to have considered the question when these mountains started to bear their modern names, and what consequences the answer to this question might have for his argument of toponymical and political movement from Sumatra to Java.

In the third place, Mahdi makes egregious use of the first indigenous document to use the term Yavadvippa, namely the Sanskrit inscription of Canggal dating to $732 \mathrm{CE}$, which against all common sense is forcibly read as documenting a transplantation of a polity of that name from Sumatra to Java. To this end, he insists on an idiosyncratic literal interpretation of the preterite form $\bar{a} s \bar{t} t$ at the start of the narrative portion of this inscription, in stanza VII:

\footnotetext{
āsīd dvīpavaraṃ yavākhyam atulan (dhā)[nyā] divìjādhikaṃ

sampannam kanakākarais tad amarais sva[rggād] i[v](o)pārjitam.

śrīmatkuñjarakuñjadeśanihi[taṃ] [ga]ṅgāditīrthāvrtạ̣

sthānan divyatamạ̣ śivāya jagataś śa[mbho]s tu yatrādbhutam• $\|^{31}$

'There once was this excellent island called Yava, abundant in grains such as rice, endowed with gold mines, as though procured by the immortals from heaven, and $(t u)$ where there was the most heavenly astonishing sanctuary of Siva, situated in the illustrious land of the Elephant's tusk (kuñjarakuñja), surrounded by bathing places such as the Gangā, bringing prosperity for the people. ${ }^{32}$
}

30. Cf. on the Central Javanese Merapi the references collected by Noorduyn (1982: 423-424, 439 n. 4) and Kuntara Wiryamartana (1990: 299-300 and 1993: 503-505). On the inscription of West Sumatra, see the rather unsatisfactory edition by de Casparis (1995: 923).

31. Text constituted by myself on the basis of an estampage kept in Leiden University Library. Variant readings vis-à-vis Kern (1885), Chhabra (1965) and Sarkar (1971-72, vol. I): (a) atulan $($ dh $\bar{a})[n y \bar{a}]^{\circ} \diamond$ atulandhā $(n y \bar{a})^{\circ}$ Kern; atula $(n d h \bar{a} y y \bar{a})^{\circ}$ Sarkar. (b) amarais sva[rggā]d i $[v](o)$ pārjitam. $\diamond$ amarai — - dinopārjitam Kern; amarai mantrādinopārjitam Sarkar; amarais svarggādino[vo?]pārjitam Chhabra (p. 47). The syllable read as ${ }^{\circ} i^{\circ}$ by all predecessors rather seems to me like a ${ }^{\circ} d r i^{\circ}$. The spelling with $m \cdot$ rather than anusvära at the end of the pāda is certain; Sarkar's amarai (for expected amarair) is ungrammatical, and the traces of following ssv are unmistakeable. (c) nihi[tam] $\diamond$ Chhabra Sarkar; nihi[ta] Kern (unmetr.). - [ga]ñgāditīrthāvrtam $\diamond$ thus Chhabra (p. 46); ${ }^{\circ}$ rotam Sarkar (printing error?); vańsáditìvādhrtam Kern.

32. On the interpretation of this stanza, see also Bernet Kempers (1967) and Stutterheim 
About the use of the past tense here, Waruno Mahdi affirms that it is "only understandable if not Java, but a Yavadvipa in Sumatra [...] is implied". The author is evidently unaware that this is an entirely commonplace way for any Sanskrit story to be opened, and that Sanskrit (verse) inscriptions obey faithfully the conventions of Sanskrit (narrative) poetry. ${ }^{33}$ The instigation towards this interpretation is another naively literalistic reading, namely of the characteristic sampannam kanakākarais, which means 'endowed with gold mines'. The conventions of Sanskrit literature oblige a poet to affirm that natural surroundings are rich in gold even if this is contrary to fact. 34

(1939). Stutterheim (p. 84, n. 1) had already rejected an argument of J.L. Moens, who had argued precisely as does Mahdi with regard to $\bar{a} s \bar{t}$, and drawn the conclusion that in his "opinion the word $\bar{a}$ sit furnishes no proof for the hypothesis that the kingdom of Sañjaya's father was situated outside Java". Mahdi, who is oblivious to this pertinent secondary literature, and hence freely proposes as his own a theory that had been advanced and rejected already many decades ago, cites a translation only of the first half of the stanza, thus escaping from the obligation to find a way to force the geographical elements we find here into the straightjacket of his theory.

33. Indeed, Sheldon Pollock, in his seminal book which is mandatory reading for any scholar who wishes to make historical use of epigraphical Sanskrit praise poems (praśasti), has observed that the Canggal inscription is "nearly a textbook example of the Sanskrit praśasti" (2006: 131). Within Javanese epigraphy itself, the use of àsit is seen also at the opening of the Sanskrit inscription of Dinaya (or Kāñuruhan), and repeatedly in the Sanskrit portion of the stela of Pucanan (also known as the Calcutta Stone), stanzas V, XI, XXIII. From Sanskrit inscriptions elsewhere in Southeast Asia, not to mention epigraphical and other written sources from India, the number of examples could be multiplied at will. The burden of proof is on Waruno Mahdi to demonstrate that all these examples must be interpreted as having a contextually significant historical past tense reference, and hence to prove wrong the inclination of Sanskrit scholars to interpret these forms as situating the narrative in a dehistoricized ('mythical') past. I may also point out that the verb form $v u^{\circ} a r a$ 'There was...', opening the narrative of the Old Javanese inscription Vanua Tnah III (Boechari 2012: 484), is clearly calqued on this Sanskrit model.

34. See Michel (2011: 13), about the Sanskrit poetic convention called 'Description contrary to reality' (asato nibandhanam), "for example things invariably described a certain way though such is not necessarily the case in reality, like mountains always described as rich in gold and precious gems". We see the force of the same poetic convention at work when, several centuries after the Canggal inscription, the poet of the Vurare inscription from East Java, writes (cf. the edition of Poerbatjaraka 1922, who read ${ }^{\circ}$ sämarthyam kumbha ${ }^{\circ}$; my edition from EFEO estampage):

ratnākarapramāṇān tu dvaidhīkrtya yavāvanīm

kșitibhedanasāmarthyakumbhabajrodakena vai

'After the division of the land of Yava, that is endowed with mines of jewels, by use of Jar- and Vajra-water, powerful enough to effect the division of the earth ...'

It is very likely that the poets of the Canggal and the Vurare inscription were influenced by the model of the 'primordial Sanskrit poem' (ādikāvya), Vālmīki's Rāmāyaṇa, which mentions a Yavadvīpa in stanzas 4.39.28-29:

giribhir ye ca gamyante plavanena plavena ca |

ratnavantạ̣ yavadvīpạ̣ saptarājyopaśobhitam \|

suvarṇarūpyakaṃ caiva suvarṇākaramaṇụitam |

yavadvīpam atikramya śiśiro nāma parvatạ \|

'And you must go to those islands that can be reached from mountains, by swimming or 
For Mahdi, however, "reference to goldmines points to Sumatra or the Peninsula, but practically excludes Java as likely location". Again we see how ignorance of basic characteristics of Sanskrit composition can lead a scholar to far-fetched interpretations. When Mahdi affirms that "The central message of the Canggal inscription is evidently that Sanjaya had [...] attained the formal rank that allowed him to challenge Sri Vijaya", one cannot help but wonder how this scholar manages to read so much into a text which says not an iota about Śrīvijaya.

This Canggal inscription has so far been understood by most scholars as saying what it says, namely that Sañjaya has installed a linga of Śiva in the year 654 Śaka, and that this king intended to declare with this installation as much as with the inscription itself his sovereignty over Yavadvipa. That this referred to the realm of this Javanese king, and Javanese kings in centuries to follow, is easy to demonstrate by juxtaposing various extracts from inscriptions found on Java, which reveal that yavadvippa, yavabhū, yavabhümi, yavāvanī, yavapura (in Sanskrit) and bhümi (ri) java, nūṣa java or simply java (in Javanese), all functioned as synonyms. ${ }^{35}$

The inscription of Rukam (Central Java, 829 Saka), for example, invokes

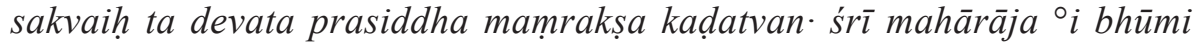
java 'all ye celebrated gods who protect the kingdom of his majesty in the land of Java' (plate II verso, line 14), ${ }^{36}$ using a phrase that is found in a

by boat: to Yavadvīpa rich in jewels, splendid with its seven kingdoms, and to Suvarnarūpyaka ornamented with gold mines. Beyond Yavadvīpa, there is a mountain called Śiśira.'

I cite here from the text as constituted in the critical edition and the translation of Lefeber \& Goldman (1994).

35. The identity of Java and Yava (and derived names) is now and again called into question, but never, as far as I can see, with solid arguments. This identity emerges from the sources themselves. Although the issue is, therefore, not directly relevant to my argument, I may state here that there is no doubt in my mind that the most original name is Java, and that yava was chosen at some point as a fitting Sanskrit word to serve as an equivalent. The similarity in sound of the Sanskrit word to the indigenous name obviously played a major role, whereas meaning was less important. We see similar phenomena throughout ancient Southeast Asia. Indeed, other important nations of ancient Southeast Asia likewise knew similar sounding doublets of names, roughly corresponding to the difference of linguistic context between Sanskrit and vernaculars. See the table below on p. 71. In most cases we lack hard evidence to decide which of Sanskrit and vernacular forms was model and which copy, but common sense suggests that the indigenous name was generally the model of the Sanskrit one. Thus for instance we find Pāṇụranga presumably mimicking Panran in Campā, although the oldest attestation of the indigenous name is younger than that of the Sanskrit equivalent. If this assumption is correct, the literal meaning of Pāṇuranga ('Pale Color') presumably played little role in this matter (cf. Griffiths \& Southworth 2011: 285-288), and likewise the literal meaning of yava 'barley' was not, I think, very relevant in it becoming applied to Java.

36. Ed. Titi Surti Nastiti et al. (1982: 23-26). I have verified the reading by autopsy of the plates. For more discussion of the formula, frequently attested with mataram standing in the place of java, see Barret Jones (1984: 5). 
number of variants through the history of Javanese epigraphy, ${ }^{37}$ and also has a parallel in the late- $7^{\text {th }}$ century inscriptions of Śrivijaya, where we read (in more than one inscription) kita savañakta devata mahardhikasannidhāna mamrakșa yam kadatuan. śrìvijaya 'all you gods, whose presence is benevolent, protecting the kingdom of Śrīvijaya'. ${ }^{38}$ The author of the versified Śivagrha inscription (778 Śaka, Central Java) was clearly alluding to the same kind of phrase when he wrote about a king mañrakșa bhümi ri java 'protecting the land of Java' (stanza VI). ${ }^{39}$

The term Yavadvīpa does not seem to occur in any other inscription of Central Java than the Canggal inscription, but it becomes very common in the epigraphy of East Java a few centuries later. Thus for instance the Tuhañaru inscription (1245 Śaka) invokes kita prasiddha rumakșan yavadvipamandala 'you celebrated ones who protect the orbit of Yavadvīpa', evidently meaning the same thing as did authors of the cited Central Javanese inscriptions, except that the center of government (and perhaps the boundaries) of Java had shifted in the meantime. ${ }^{40}$

In this later period, a particularly common expression is sa(kala)yavadvippa 'the entire island of Java', typically used in the eulogistic opening parts of inscriptions to indicate the territorial claims of the kings of Singasari and Majapahit. Some of these passages explicitly express the equivalent of this Sanskrit expression in Javanese. Thus, for example, the inscription of Mūla-Malurun் (1177 Śaka) refers to king Krtanagara as

śrīsakalayavadvīpanaranāthādiguru, sira saṃ pinakaguru dainiṃ samaptagrāma, samastakṣatriya, makādi sakvaiḥnira prabhū ṅke riṃ nūṣa java ${ }^{41}$

37. The meaning of prasiddha in such phrases is not certain. Always keen to seek connections with ancestor worship, Stutterheim (1927: 188) was convinced that devata prasiddha denotes deceased kings who had become deified. But in the undoubtedly related context of the stanzas V and VI of the Sivagrha inscription, de Casparis (1956: 311-312, 316-317) gave it one of its basic Sanskrit meanings, i.e. 'perfect'. I choose here the other basic Sanskrit meaning.

38. See Boechari (1979: $38-40=2012$ : $381-384)$ for a synoptic edition. Whereas previous scholars have seen two separate words in the sequence mahardhikasannidhāna, it seems to me most natural to interpret it as as a bahuvrīhi compound. Cf. also kāmu mamrakșãña sakalamandalāña kadātuanku 'you who protect the entire orbit of my kingdom' in 1. 20 of the Sabokingking (Telaga Batu) inscription from Palembang, also late $7^{\text {th }}$ century (de Casparis 1956: 15-46).

39. Stanza VIII possibly contains a more elaborate allusion, but the reading published by de Casparis (1956: 312) is almost entirely unverifiable on the stone (National Museum, Jakarta, D.28): nātha prasiddha ri jagat ni $\_\_\_\_$rakșā ni rovañ atha vīra varuh svaśīla $\mid$kālap kalāgunaraviprakulasthanāma ginlar ri mamratipurastha madañ kadatvan 'A king, perfect in (this) world, ....., a protection for his comrades, indeed a hero who knew the duties of his rank; he adopted a name proper to a family of honourable Brāhmanas (rich in) arts and virtues, and established his kĕraton at Meḍang situated in the country (?) of Mamrati'.

40. Cf. on this shift of the center of government Boechari $(1976=2012$ : 155-181) and Barret Jones (1984: 6-7).

41. Plates I verso line 7 through II recto line 1. Ed. compiled on the basis of readings by Titi 
'(in Sanskrit:) the primordial teacher (ádiguru) of all the (vassal) kings in Java, (in Javanese:) the one who served as teacher to all settlements, all noblemen, to begin with all (vassal) kings here in the island of Java'

If any doubt remained about the equivalence of yava(dvīpa) and (nūsa) java, and about the assumption that the island of Java itself is designated thereby, then it seems that this passage, with its emphatic ike 'here', should be sufficient to dispel it. Several more expressions of the type $s a$ kalayavadvipa(mandala) have been assembled from East Javanese inscriptions by Damais (1957: 617), and need not be reiterated here. ${ }^{42}$ It is likely that we are dealing with an early Central Javanese equivalent when in the inscription of Vanua Tñah III (plate II recto, lines 6-7) ${ }^{43}$ we encounter a sentence: kumonakan' sam hyam dharmmā bihāra ${ }^{\circ}$ java kabaih svatantrā ${ }^{\circ}$ umāryya kadandān 'he issued an order with regard to the sacred monastic foundations on all of Java that they be fiscally exempt and cease to be taxed' (although kabaih 'all' here might alternatively qualify the 'monastic foundations'). ${ }^{44}$ Indeed, the Javanese epigraphical data make it hard not to agree with Damais, who wrote (1964: 127):

Il semble évident que Jawa et Yawa - les deux formes javanaise et sanskrite - ont dû être employées côte à côte par les étrangers pendant la période la plus ancienne aussi bien qu'à Java pendant la période épigraphique où différents documents sont là pour nous le prouver, même à une date beaucoup plus tardive. ${ }^{45}$

In this general light, and in the specific light of the fact that the metrical Old Javanese inscription of Śivagrha of 778 Śaka already used the expression bhümi ri java (where the insertion of $r i$ is likely to be metri causa), it is hard to understand why many scholars have been reluctant to interpret bhümi jāva

Surti Nastiti and others, by Hadi Sidomulyo (2010: 106-114); verified on the basis of photos of the plates kindly put at my disposal by Titi Surti Nastiti. The reading samaptagrāma is not acceptable, and must be emended to samastagräma, as is assumed in my translation, or else to samastāiśrama.

42. Since aiming at exhaustivity is not useful or realistic in the present context, I add here only reference to the already mentioned Vurare inscription, whose stanzas V (yavāvanīm), VI and IX need to be read in parallel with the Sarvadharma inscription (ed. Brandes 1913, nr. LXXIX, pp. 188-193), plates III through IV, and to the Pucanan inscription (ed. Kern 1917: 83-114), which uses the term yavadvipa throughout, both in Sanskrit and in Old Javanese. For further variants on the names of Java in Javanese epigraphy, I refer to Damais (1964: 126-130).

43. Edition Boechari (2012: 484-491); verified by autopsy of the plates.

44. It will be observed that in some of the later contexts of sakalayavadvipa too, the adjective sakala contextually needs to be applied to a sentence constituent other than yavadvipa, as in the example above, where it qualifies naranātha.

45. Damais' use of $w$ rather $v$ to spell these names is in conformity with his transliteration conventions, which are different from mine. His Jawa/Yawa are strictly identical to the names that I prefer to represent as Java/Yava in the present paper. 
in the Śrivijayan inscription of Kota Kapur, on the island of Bangka, as denoting (some part of) Java. ${ }^{46}$ The passage is as follows (lines 9-10): ${ }^{47}$

\begin{abstract}
śakavarșātīta 608 diṃ pratipada śuklapakṣa vulan· vaiśākha • tatkālāña yaṃ maṃmaṃ sumpah ${ }^{\circ}$ ini • nipāhat · di velāña yaṃ vala śrīvijaya kalivat · manāpik · yạ̣ bhūmi jāva tida bhakti ka śrīvijaya

'Elapsed Śaka year 608, on the new moon day of the bright fortnight of the month Vaiśākha. That was the time that this admonitory imprecation was engraved, on the occasion that the forces of Śrivijaya passed to attack the land of Java which was not subservient to Śrīvijaya'.
\end{abstract}

Waruno Mahdi has recently presented an argument that bhümi jāva in this passage would refer to a polity (Malayu) in the Batang Hari river basin (2008: 118-121), being unaware that Boechari (1979: $31=2012: 377$ ) has presented another argument that it referred to a place in Lampung, or that Claude Jacques has recently argued that it denoted a place in the Malay Peninsula. In his last statement on the problem, Boechari admits: "We still could not find reasonable grounds for supposing that with Bhūmi Jāwa in the inscription of Kota Kapur was meant West Java or the kingdom of Tārumānagara [...], or Central Java [...]" (1986: $48=2012: 398)$. Even though we are 170 years before the earliest attestation of the term bhümi java on Java itself, this manner of viewing things seems aberrant to me. The question the historian should ask is rather whether he can find reasonable grounds for supposing that bhümi jāva here means anything else than Java. In my opinion, neither Boechari, nor Jacques, nor Mahdi has succeeded in demonstrating that there are such reasonable grounds. Evidence will be presented below suggesting that Java was already known under precisely that name to people on the mainland as early as the beginning of the $7^{\text {th }}$ century.

\title{
Yava and Java in inscriptions of Cambodia
}

In a recent article devoted to certain passages in a long Sanskrit inscription of Cambodia issued under Jayavarman VII, the stela of the Prah Khan (K.908, 1113 Śaka), Claude Jacques (2005) takes exception to the received interpretation of its stanza CXLVI, standing at the end of a section of the text describing an annual temple festival in the month of Phālguna:

46. The spelling difference (java in Old Javanese, jāva in Old Malay) is certainly not a ground for objection. For the use of non-phonemic vowel lengthening in penultimate syllables is an orthographical feature of Śrivijayan Old Malay, probably corresponding to a pattern of penultimate stress or accent in the language (cf. Mahdi 2005: 189). Ferlus (2010: 69 n. 5) agrees: «ces différences de forme ne sont pas significatives». Claude Jacques' remark on this matter (2005: $21 \mathrm{n}$. 16) reflects his insufficient familiarity with the corpus of Old Malay inscriptions.

47. Ed. Cœdès (1930: 46-50); verified on the basis of the EFEO estampages, as well as photos of the stone. 
dvijāśs śrīsūryabhattāāyā javendro yavaneśvarah cāmpendrau ca pratidinaṃ bhaktyā snānāmvudhārinah

'Brahmins with Śrī Sūryabhatța at the head, the king of Java, the lord of Yavana and the two kings of Campā, every day devotedly offer bathing water.'

George Cœdès, the editor of this inscription (to which we shall briefly return below, p. 70), had interpreted this stanza as expressing that the mentioned kings were vassals to the king of Cambodia (1941: 267-268), and he assumed that the stanza referred to the kings of Java, of Annam (i.e. Đại Việt, yavana) and of Campā. He explained that

La vassalité était effective pour les deux rois du Champa; elle devait l'être infiniment moins pour le roi de Java et surtout pour l'empereur d'Annam. Mais on sait avec quelle facilité les souverains orientaux acceptaient une suzeraineté nominale qui ne les engageait à rien et leur assurait la bienveillance de puissants voisins.

To this interpretation Jacques objects with the following argument (2005: 17).

\begin{abstract}
Jusqu'à preuve du contraire, il semble que les poèmes sanscrits, qui s'adressaient directement aux dieux, s'ils souffraient évidemment de larges hyperboles dans leurs comparaisons, se refusaient à énoncer des contrevérités factuelles. Nous pouvons certes, sous réserve d'une connaissance meilleure de l'état politique du Campā au XII ${ }^{\mathrm{e}}$ siècle, être d'accord avec G. Cœdès lorsqu'il précise au sujet des «deux rois du Champa» que cette vassalité devait être «effective» au moment de la composition de ce poème [...] Cependant, s'il est juste qu'il est en effet peu vraisemblable que le «roi de Java» - à supposer que javā désigne l'île - et l'empereur d'Annam - ou plus précisément le roi du Dai-Viet - aient jamais fait acte de vassalité envers le roi khmer, fût-il Jayavarman VII, il est légitime de se demander si ce qui paraît une invraisemblance ne cache pas plutôt le fait que George Cœdès aurait mal identifié géographiquement les sites correspondant aux Javā et aux Yavana.
\end{abstract}

This argument amounts to a willful denial of the nature of royal inscriptions as instruments of propaganda, that we see throughout the Indianized world, and the corollary that attempts of $19^{\text {th }}$ and $20^{\text {th }}$ century Western historians to build histoire événementielle by treating epigraphical data as factual descriptions of historical events need to be treated with utmost care. That is, Claude Jacques chooses to deny just about the most important advance in historiographical understanding in the study of pre-modern South and Southeast Asian history of the past few decades (cf. Pollock 2006: §3.3). And this methodological atavism becomes the starting point for a wild goose chase in search of alternative identifications of Java/ā and Yavana, which Jacques finds respectively in "un royaume vassal de population malaise" and "les Thaï". But as soon as we accept that the Khmer king was just as liable to make counterfactual claims to suzerainty over his neighboring kings, as were his peers throughout the epigraphically recorded history of the entire Indianized world - including the kings of Java (see my citation of the Mūla-Malurun inscription above, p. 59) - the very basis of Jacques' reasoning falls away, and we no longer have any ground to refuse to 
acknowledge what the epigraphical evidence clearly reveals, namely that in the inscriptions of Campā and Cambodia the terms Java and Yavana referred to Java and Đại Việt. I will briefly return below to the issue of Yavana, but my focus must remain on Java.

Jacques rightly observes that the Khmer corpus mainly attests the form Javā, and only once mentions Yavadvipa. He then deals with the toponymic evidence from the island of Java in no more than one paragraph of five lines, mentioning only the inscription of Canggal with its Yavadvīpa, "sans pourtant être assuré que l'auteur de ce texte désigne effectivement l'île qui porte ce nom aujourd'hui'. It is only by totally ignoring all the evidence presented above, and the work of predecessors such as Louis-Charles Damais, that the rarity of cases of Yavadvipa in Khmer epigraphy can for Jacques then become an argument to support his claim that the Khmer inscriptions did not mean the island of Java when writing Java/ā, and that bhümi jōva in the late- $7^{\text {th }}$ century CE Śrīvijayan Old Malay inscription of Kota Kapur would denote the Malay peninsula rather than the island of Java.

Having determined that Claude Jacques's arguments cannot stand scrutiny, let us now simply present the few passages from Cambodian epigraphy where we find reference to Java or Yavadvīpa, other than the inscriptions quoted at the outset. The earliest possible reference, not so far acknowledged by any scholar as far as I am aware, is found in the inscription of Vat Cakret (or Preah Vihear Kuk; K. 60, 548 Śaka; ed. Barth 1885: 38-44), from the Ba Phnom region in the heart of Funan, present Prei Veng province in the far South of Cambodia:

rājendrasya prasādena dinmaṇụalavicār(iṇaḥ)

pareșām kīrttim ākramya yasya kīrttir jjavasthitā

The editor of this inscription, Auguste Barth, took the word java as the Sanskrit noun meaning 'speed'. He proposed:

Par la grâce de ce roi des rois (i.e. İsānavarman), parcourant le cercle (entier) des régions, lui dont la gloire après avoir attaqué la gloire de ces rivaux, s'est arrêtée dans sa course rapide ...

On the word javasthitā, 'arrêtée dans sa course rapide', he gave the explanatory note: «Pour se reposer, sans doute, et se fixer auprès de lui. Ou faut-il traduire : “(n'en) est devenue (que plus) rapide”?». It seems almost certain to me that a pun was intended here, and that besides the claim that the king's fame is (oxymoronically) 'steadfast (sthitā) in rapid motion (java)', the poet here intended to claim that the king's fame had travelled to great distance and was 'present (even) in Java'; in other words, that he intended to present a variant of the trope of royal fame being disseminated far and wide which is exceedingly common in Sanskrit poetry. In support of this suggestion, I can refer to an inscription of Campā, C. 211 (820 Śaka; 
Griffiths et al. 2012b: 265), where we read on face B, in stanza III:

kīrttiṃ sthitām api mahāmvunidheś ca pāre

puṇodayam̆ krrtavato bhuvi rājamārggam

manye guṇā dinakarānśusamās tamondhe

yānty asya kim̆ punar ime svapure prakīrṇnāḥ \||

'I imagine that the fame of him (Jayasimhhavarman), who has fashioned a royal highway on the earth [in the form of] his abundant merit, is present even on the opposite shore of the great ocean. His virtues, spreading out, like rays of the sun, penetrate (yanti) [even] in pitch darkness. How much more throughout his own city!'

If this suggestion is correct, then the stanza of K. 60 implies contact between the Khmers and a distant foreign polity known to them as Java already in the early $7^{\text {th }}$ century CE. It is an attractive speculation to suppose that this polity was situated on the island which still bears this name.

The next reference comes from an inscription from Angkor of the late $9^{\text {th }}$ century (K. 809, 80x Śaka; ed. Cœedè 1937-66, vol. I, p. 37), which states of king Indravarman, in stanza XX on its Southern doorjamb:

cīnacampāyavadvīpabhūbhrduttungamastake yasyājinā mālatīmālānirmmåā cumvalāyate \|

'His decree, immaculate as a garland of jasmine, forms a crown ${ }^{48}$ on top of the lofty heads of the kings of China, Campā and Yavadvīpa.'

Besides the two Sanskrit stanzas from K. 60 and K. 809, I must mention the use of the term javā in a list of cult objects in the inscription K. 947 (815 Śaka), about which I may cite from Dominique Soutif's doctoral thesis (2009: 174):

..., il nous reste à évoquer Javā, pays pour lequel nous disposons de l'unique mention d'un objet importé d'un pays proche du Cambodge. Elle apparaît [...] dans l'inscription K. 947 A : on y relève en effet l'objet suivant : vodī camdoñ prak garop prak tamve javā I jyan் 4 lin II, «1 vodī [pourvu d'] un bec en argent, avec un couvercle en argent, travail de Javā, [pesant] 4 jyan், 2 liǹ»; comme on le voit, on retrouve encore une fois le terme tamve $(1.26 ;[\ldots])$. [...] Cette nouvelle occurrence n'apporte malheureusement aucun élément permettant de localiser ce Javā. Cependant, il est intéressant de noter que ce pays entretenait manifestement des relations commerciales avec le Cambodge moins d'un siècle après que Jayavarman II ait effectué un rite destiné à permettre au royaume khmer de se dégager de sa tutelle.

Finally, there are a meager two occurrences in lists of persons. There is a lon java in a context from which we gain nothing in K. 366 (Vat Phu, 1061 Śaka; ed. Cœdès 1937-66, vol. V, p. 288), face B, $1.14 ; 49$ and there is a kurek javā in a context which also figures a vāp cāmpa and a vāp cām, suggesting involvement of people of foreign origin, in K. 165 (Thvar Kdei, Kompong Thom province, 874-79 Śaka; ed. Cœdès 1937-66, vol. VI, p. 132), face N,

48. See Bhattacharya (1991: 15, 49).

49. If the reading java, with short final $a$, is correct (which does not seem totally certain on EFEO estampage n. 799), then we may not be dealing with the name that concerns us in this paper, but with the Sanskrit word java 'speed'. 
1. 38. ${ }^{50}$ None of the evidence from Cambodia thus provides any internal hint as to the identity of Java and Yavadvipa known to the ancient Khmers. At least we can say that there is no concrete reason to doubt that these terms denoted the same place.

\section{Yava and Java in inscriptions of Campā}

Let us now turn to the inscriptions of Campā, presenting the relevant passages in chronological order. The stela of the temple of Po Nagar at Nha Trang (C. 38) recounts the history of the cult of Sambhu's 'Face-Linga' (mukhalinga) and the cult of his consort, the 'Lady' (bhagavatī or bhațāri $)$. It does so with unusual prolixity, and duplication of information in verse and prose parts of the text, on face A, in stanzas II through IV, and on face B in the prose on lines 8-11. We read about an attack, in the year 696 Saka, at the hands of foreign men, who came by ship, bearing arms, stole the linga's removable face and the image of the Lady, and took off after setting the temple on fire, thereby destroying the linga. They were pursued and slain on sea by king Satyavarman, but the linga's face was lost in the waters, along with its paraphernalia. This king was able to restore the temple with its mukhalinga and its image of the Lady to their former condition in the year 706 Śaka. For purposes of my argument below, it is sufficient to cite here from the prose narrative (face B, lines 8-9; ed. Bergaigne 1893: 74-75):

\footnotetext{
tataś cirakālakaliyugadoṣād deśāntaraplavāgatapāpanarabhuggaṇasaṃhrteșu pratimāparibhogabhūṣaneșu śūnyo bhavat

'Then, due to long-lasting faults of the Kali age, [the temple of Śambhu and the Lady] became deserted after the images, paraphernalia and ornaments had been robbed by hordes of evil cannibals who had come by boat from abroad.'
}

This inscription does not identify the ethnic identity of the foreign attackers. But from an inscription issued by Satyavarman's younger brother and successor, Indravarman (C. 25), we learn that just three years later, in 709 Śaka, foreign forces struck again. Again they arrived on ship, and this time the object of their vandalism was the temple of a god Bhadrādhipatîśvara that must once have stood in Pāṇuranga, the Cam heartland not far south of Nha Trang, that was the center of power of Satyavarman and his successors. ${ }^{51}$ This inscription, issued on the occasion of restorations carried out in 721 Saka, is less elaborate in its account of the event, but its description (face B, lines 6-7) is strikingly similar to the prose passage from C. 38 that I have just cited:

50. The terms loñ, vāp and kurek are untranslatable indicators of social status in Old Khmer. Jacques (2005: 20, with $n$. 14) has referred to a Yavapura in an inscription from the Battambang region. In this case we can agree with him that this was «certainement un toponyme local».

51. For a survey of the relevant sources and what we know about this line of kings, see Griffiths \& Southworth 2011. 
tataś ca kaliyugadoșātiśayabhāvena nāvāgatair jjavavalasaṃghair nnirddahyate pi navāmvarādriyamite śakakāle sa eva śūnyo bhavat ${ }^{52}$

'And then, because of the excessiveness of the faults of the Kali age, [the temple of Bhadrādhipatīśvara] was even burnt by hosts of forces of Java, who had come by ship, in 709 Śaka. In this way it became deserted.'

The verbal parallelism between the accounts of attacks in 696 and 709 Śaka is such as to suggest that forces of Java were involved also in the attack of 696 under the reign of Satyavarman. ${ }^{53}$ Whether this is true or not, it is unlikely that Java in this context denoted any mainland polity or ethnic group, for even the Khmers, who would most easily have had access to a naval route, preferred to come by land when they attacked Campā, as attested by historical records. ${ }^{54}$

The next reference that concerns us here is found in an inscription from Northern Campā, C. 149 (833 Śaka), which recounts the career of a high official who served successive kings of the so-called Indrapura dynasty. In stanzas VIII and XI of this inscription we read: ${ }^{55}$

yavadvīpapuraṃ bhūpānujñāto dūtakarmmaṇi

gatvā yah pratipattisthah siddhayātrāṃ samāgamat \||

'Having been assigned by the king with a diplomatic task, this dignitary went to the capital of Yavadvipa, and met with success of his mission.'

yavadvīpapuraṃ bhūyaḥ kṣitipānujñayānayā

dvivāram api yo gatvā siddhayātrām upāgamat ||

'By this (same) assignment of the king he again went to the capital of Yavadvipa, and even the second time obtained success of his mission.' 56

The term Yavadvīpa occurs again in the much later inscription C. 22 (no earlier than 1228 Saka), which states in Old Cam, in lines 2-4 of face A: ${ }^{57}$

52. Ed. Bergaigne (1893: 33); verified on EFEO estampage n. 1952. It seems that eva must be emended to evam, as my translation presupposes.

53. This was assumed as a fact by Codès (1968: 95). The likelihood that we can indeed identify the attackers of 696 Saka $(774 \mathrm{CE})$ is strengthened by the fact that Chinese accounts of an attack of "Java” (阇婆, Mandarin Shepo, Vietnamese Đô bà / Trà và) on an area which now lies in northern Vietnam, in $767 \mathrm{CE}$, just seven years before the first recorded attack on Campā. See the first footnote in Claudine Salmon's contribution to this issue, and its section entitled "The Jawa or Di nhân".

54. See Wolters (1973: 28-29 = 2008: 173-174) and Lepoutre (forthcoming).

55. Edited by Huber (1911: 303) and Majumdar (1927: 131). With regard to stanza VIII, it is not clear whether Majumdar's reading $\bar{d} \bar{u} t a^{\circ}$ in place of Huber's nüta ${ }^{\circ}$ is a conscious new reading or emendation, or the mere result of faulty copying from Huber. However this may be, direct inspection of the stone (National Museum of History, Hanoi: B2, 28 = LSb 21154) reveals that $\bar{d} \bar{u} a^{\circ}$ is the correct reading.

56. On the term siddhayātrā, see Nilakanta Sastri (1937, 1948-49) and Chhabra (1948). Several of the contexts in which it occurs in Sanskrit literature explicitly involve travel by sea.

57. I cite these lines in a provisional edition based on my own inspection of the EFEO estampage n. 1073. The text is badly preserved in parts, and I do not fully understand the 
madā agrarājamahiṣi sidah rājaputrī pu poñ tana rayā (d)evādideva ${ }^{58}$ ya marai jem̃ vyā parameśvarī ya samū bhagavatī (śrī) $\{1\}$ sahajotpati $\{1\}$ yam̃̃(n) $\cdot$ madā rājaputrī pu poñ tana rayā yavādhipa ya marai di yavadvīpa ya drrm̃ nāma sidaḥ pu poñ vyā tāpasī

'There was an excellent chief queen, namely the daughter of his majesty the Super-God among Gods, who came to become his queen. She was like the Lady Srī ... natural birth ... There was a daughter of his majesty the lord of Yava, who came from (?) Yavadvipa. She bore the name Pu Poñ Vyā Tāpasī.'

The remaining passages from Campā inscriptions are in lists, formulated in Cam language, of slaves (hulun) attached to the service of certain sanctuaries. These are as follows.

C. 7 (end of the $12^{\text {th }}$ century Śaka), 11. 3-4: ${ }^{59}$

kvi[r]· ja[v]ā laum̃ vukāṃ sya(ṃ) [\#]3 driñ̃

'Khmers, Javanese, Laos/Chinese, Paganese, Siamese: \#3 people [in total]'.

C. 10 ( $13^{\text {th }}$ century Śaka), 1. 5: ${ }^{60}$

... vinai javā vinai lamvī vinai yvan· lakim̃ ranuk ...

'... Javanese woman, woman (of) Lamvī, Viet woman, man (of) Ranuk...'

C. 43 (after 1357 Śaka), face B, 11. 21-23: 61

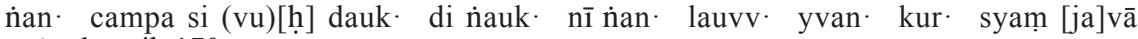
vañgalā avih 170

'And [men'] of Campā whom he ordered to reside here in the highlands, with Laos/Chinese, Viets, Khmers, Siamese, Javanese, Bengalis: all of them 170.'

Again, as in the case of the evidence from the inscriptions of Cambodia, we see that the data from the inscriptions of Campā are not in themselves sufficient to identify what the terms Java/Javā and Yavadvīpa referred to. But there is no reason to assume that they did not denote the same place. We may at least surmise that this place lay overseas, and that Campā maintained connections diplomatic and otherwise - with it over a period of several centuries.

\section{Cams, Khmers, and other foreigners in the Javanese historical record}

Having seen how in records of the Cams and the Khmers the terms Yavadvipa and Java often occur in the context of lists of foreigners or

passage in question at the time of this writing. See Vickery (2004: 55-58) on the history of interpretation of this passage. In response to Vickery I can confirm here that the reading javādhipa, once entertained by Finot, is certainly not correct, and that Aymonier's improved reading of 1911 must be accepted. This reading was subsequently 'rediscovered' by Jacques (2005: 21) who ignores Aymonier's publication.

58. Probably to be understood as devādhideva (cf. the very common Sanskrit expression rājādhirāja).

59. Cited after the edition of Lepoutre (forthcoming), used also in Griffiths \& Lepoutre (forthcoming).

60. This unpublished inscription is cited from my provisional reading based on EFEO estampage n. 1949.

61. Ed. Griffiths et al. (2012b: 205ff.). 
foreign countries, it will be useful for my argument to review briefly how Javanese sources refer to foreigners. ${ }^{62}$ This occurs most notably in lists of 'tax farmers' (kilalan), ${ }^{63}$ whose oldest instantiation we find in the damaged Kalirunan inscription, presumably from Central Java, of 805 Śaka (Boechari 2012: 477-478), and then in a substantial number of inscriptions of following centuries, all from East Java. The lists show only slight variation from the earliest to later specimens, and the development of their composition has been described by Wisseman Christie (1999: 246-248). It is sufficient here to cite only the earliest fully preserved example, from the inscription of Cane (943 Śaka), line 14: ${ }^{4}$

kunañ ikanan் vārgga kilalan klin āryya sinhhala panḍikira draviḍa campa kmir ṙmən ...

'and the tax farmer groups of Klin, Ârya, Singhalese, Paṇịikira, Draviḍa, Cams, Khmers and Mons...'

The segment campa kmir ramon occurs (in various spellings) in all attestations of such lists, and has unanimously been interpreted as denoting Cams, Khmers and Mons. ${ }^{65}$ Outside of these lists, the material from Javanese epigraphy is very limited. Besides one inscription where the fact that a person is 'considered to be of Khmer descent' (sinanguh vka kmir) is relevant for his tax status, ${ }^{66}$ we only find occurrences of Campa and Kmir that are of no relevance to the present study. ${ }^{67}$

Different from the cases of ancient Campā and Cambodia, however, the ancient Javanese historical record is not limited to epigraphical sources. The court poem Deśavarnana (formerly referred to by scholars as Nāgarakrtāgama) in praise of the Majapahit king Hayam Vuruk contains important information on the foreign countries, beyond the sphere of influence of

62. Barret Jones (1984: 23-26) has discussed the pre-11 th century CE epigraphical sources relevant to this matter.

63. On this term, see Boechari (1976: $7=2012$ : 166 with n. 16) and Zoetmulder (1976: 191).

64. Edited in Brandes 1913, nr. LVIII, p. 124.

65. On rəmən, see Wisseman Christie (1999: 245-248) and Krom (1914). I may note here that the name $\mathrm{klin} / \mathrm{khlin}$ is also attested in Khmer epigraphy, and is commonly interpreted as referring to (some part of) India (thus e.g. Jenner 2009a: 82 / 2009b: 74), as is the evidently identical Javanese name $k($ a) lin (e.g. by Wisseman Christie). The important observations of L.-Ch. Damais (1957: 635-636 and 1964: 94-104), giving a cautious argument in favor of a location in the Malay Peninsula, are habitually ignored. The occurrences in Khmer epigraphy more than once show the ethnonym ramañ 'Mon' in the immediate context.

66. Inscription of Vuruḍu Kidul, verso, line 10 (844 Śaka), edited by Stutterheim (1935: 451-452).

67. See the plate of Guntur, recto, lines 5-6 (829 Śaka; Sarkar 1971-72/II: 100) for a Si Campa and the stone of Turyan, face A, line 37, for a San Campa (Titi Surti Nastiti 2003: 147); the plate of Paləpanan, line 13 (Sarkar 1971-72/II: 56) for a man called Pu Kmir and the inscriptions of Ratavun I and II, respectively recto line 11 and line 8 (Sarkar 1971-72/I: 267 and 273), for a man referred to as si ṅgah ramani kmir 'Si Ngəh headman of the Khmers'. 
Majapahit, that were known in East Java in the $14^{\text {th }}$ century CE. First, in a stanza that comes immediately after a long list of places considered to be under Majapahit suzerainty, we read the following (15.1):

nāhan lvirnin deśāntara kacaya de śrī narapatī

tuhun tań syañkāyodhyapura kim utan் dharmanagarī

marutma mvan rin rājapura nuniveh sinhhanagarī

ri campā kāmbojānyat i yavana mitreka satatā || $15.1 \|$

'The above are the various regions protected by His Majesty; on the other hand, the Siamese of Ayodhya and also of Dharmanagarī, Marutma, Rājapura as well as Sinhanagarī, Campā, Cambodia and Đại Việt are always friends.' 68

In a different part of the text, in the context of a description of an annual festival in the month of Phalguna, we read three relevant stanzas (83.4-5):

hetunyānantarā sarvajana təka sakeñ anyadeśa prakīrṇa nañ jambudvīpa kamboja cina yavana len cəmpa karṇātakādi

goḍa mvań syańka tań sańkanika makahavan potra milvin vaṇik sək

bhikṣu mvañ vipramukhyān hana təka sinunan bhoga tușțan pananti $\|83.4\|$

ndān an̉kən phalguṇa śrī nrọati pinaripūjenivō rin svarājya

prāptan mantrī sabhūmī java juru kuvu len dhyakșa sarvopapatti

milvañ bālyādi nūṣāntara sahana saha prabhrətin tan pəgat sək

byāpārī mvañ vaṇin ri pəkən an̉əbək atip sarvabhāṇ̣anya kīrṇa || $83.5 \|$

'And so constantly all kinds of people come from other countries in countless numbers namely India, Cambodia, China, Đại Việt, Campā, the Carnatic and so on, Bengal and Siam are their places of origin, sailing on ships with merchants in large numbers, monks and priests in particular - when they come they are given food and are happy to stay.

Now every Phalguna the King is honoured and treated with solicitude in his own palace: there arrive the officials of all Java, the juru and kuvu as well as the Superintendents and all the Assessors, joined by the Balinese as first among the other islands, all with their gifts in uninterrupted numbers; vendors and merchants fill the markets and all their various wares are piled up in abundance. ${ }^{69}$

For a discussion of the identification of the foreign countries (deśäntara, anyadeśa) in these stanzas, I refer to Gerini (1905) and Robson (1997). ${ }^{70}$ It is perhaps no coincidence that the court poem of the $14^{\text {th }}$-century king of Majapahit records foreign courtesy visits in close connection with the festival in Phālguna, while the description of the Phālguna festival under the Khmer king Jayavarman VII at the end of $12^{\text {th }}$ century CE is likewise stated

68. I have cited with slight adaptations the translation furnished by Robson (1997: 431), which was itself slightly adapted from the complete translation of the Deśavarnana in Robson (1995). Here and in the stanzas below, I have normalized the spelling and made the necessary small adjustments concerning vowel length and epenthesis of the vowel $a$ in order for the text as edited diplomatically by Pigeaud (1960-33, vol. I) to satisfy the requirements of meter.

69. The translation of stanza 3 is after Robson (1997), that of stanza 4 after Robson (1995).

70. Robson ignores Gerini's publication. In my opinion, neither author succeeds in giving a satisfactory explanation of the term Syanka. Even if, like me, one is unconvinced that syanka can be explained as syam with Sanskrit suffix $-k a$, as Robson proposes, at least one may agree with him that it denoted Siam. 
to have involved numerous foreigners. We read about this in the stela of Prah Khan (K. 908, 1113 Śaka), that we have already cited above, now in stanza LVII:

atra strīpurușās sacāmpayavanās sārddhaṃ pukāṃrvvañjanair rakșyantān triśatā iha triniyutās te șaṭ sahasrā api șaștị dvādaśa cāyutan tu gaṇitās sārddhaṃ sahasratrayaṃ grāmāḥ kiñ ca na devakāryyakaranam kạșṭhopalādy akṣatam

${ }^{6}$ For this purpose, the men and women including Cams and Viets, ${ }^{71}$ together with Pagan and Mon people, numbering three hundred and six thousand three hundred and seventytwo, as well as the three and a half thousand villages, and whatever, made of wood or stone, serves for the cult of the gods, must be maintained unscathed!'72

\section{Implications of nomenclature shared between the ancient Khmers, Cams and Javanese}

We have seen that rulers of the Central Javanese kingdom in the $8^{\text {th }}, 9^{\text {th }}$ and early $10^{\text {th }}$ centuries of our era used both yavadvipa and bhümi java (and equivalent expressions) to denote their own realm, and that kings continued to do so throughout the following centuries, after the center of power had moved to East Java. The terms were obviously synonymous to the Javanese rulers themselves, and there is no reason a priori why we should not attempt to identify the contemporary ancient Khmer and Cam references besides the earlier Śrīvijayan reference to javā/java/jāva as denoting the island of Java. ${ }^{73}$

On the contrary, there is a simple and decisive argument in favor of this identification. This is the evident agreement in nomenclature both for own countries (endonyms) and for foreign countries (exonyms) that we see when

71. Based again on his misguided presumption that the claim of Khmer suzerainty over Yavana in K. 908, st. CXLVI (see above), must be factually true, Claude Jacques (2005: 25-29) has attempted to argue against the idea that Yavana here denotes Đại Việt, and to do so presents data which had long since been presented by Gerini (1905) showing that certain people in northwestern Thailand used the same name, but ignoring entirely Gerini's publication on the list of mainland polities in the Deśavarnana, and its sober conclusion that it is unreasonable to presume the author of the Deśavarnana intended such a people in northwestern Thailand rather than the Viets, to whom this term undoubtedly refers in inscriptions of Campā. If the Javanese and the Cams used the term to denote the Viets, the question becomes why the same would not hold true for the Khmers. One needs much stronger reasons than Jacques' argument based on the stanza of K. 908 to make a persuasive case. See also Vickery (2004: 9) on Yavana as term denoting the Viets in Khmer inscriptions.

72. Another inscription of the same period, K. 273 (Śaka 1108), stanza LXVII, again mentions Cams and Paganese together. On the historical background, see Lepoutre (forthcoming) and Griffiths \& Lepoutre (forthcoming).

73. Whereas the spelling jāva is found only in one source, in Old Malay, and is explained above, in $\mathrm{n} .46$, the fact that vernacular Khmer and Cam sources spell javā whereas Javanese sources spell java can be easily explained with reference to other evident cases of vocabulary that is shared by the unrelated languages Khmer and Malay/Javanese: instances such as Khmer $\operatorname{tr} \bar{a}$ 'seal' and $m \bar{a} h \underline{h}$ 'gold' corresponding to təra in (modern) Malay, zmas in (modern) Malay and mas in Javanese. In the cases of lexical correspondences between the very closely 
we compare the inscriptions of Cambodia, Campā and Java. If we limit ourselves to names attested in at least two of the three epigraphical corpora, and exclude terms that certainly refer to countries outside Southeast Asia (China and India), the result is as shown in the following table. ${ }^{74}$

Even if we admit the uncertain case of Klin (see n. 65 above), which is anyhow different from all other cases in being much less well attested epigraphically, and intentionally leave open the identity of Yavadvīpa/Java,

\begin{tabular}{|c|c|c|}
\hline Sanskrit name & Vernacular names & Identification \\
\hline Campa/Campā & Cam, Cām & Cam \\
\hline Kamvuja & $\begin{array}{l}\text { Kmer, Khmer } \\
\text { Kmir, Kvir, Kur }\end{array}$ & Khmer \\
\hline \multirow[t]{3}{*}{ Rāmanya } & $\begin{array}{l}\text { Rmañ, Ramañ, } \\
\text { Rvañ, Rəmən }\end{array}$ & Mon \\
\hline & Pukāṃ & Pagan \\
\hline & Syam $^{75}$ & Siam \\
\hline \multirow[t]{2}{*}{ Yavana } & Yvan & Viet \\
\hline & Kliṅ, Khlin் & $?$ \\
\hline Yavadvīpa & Java, Javā & \\
\hline
\end{tabular}

the pattern that emerges from this list is still clear enough: all remaining names can be identified without reasonable doubt as representing one of the major polities known from ancient Southeast Asian history. ${ }^{76}$ Moreover, both in the case of the Cams and the Khmers, their endonym as used in their own inscriptions is identical to that observed in the inscriptions of their neighbors to refer to them and their country. These facts leave no space for reasonable doubt that Java/Yavadvipa denoted the single major polity of ancient Southeast Asia which is still missing from the rightmost column in

related languages Cam and Malay, and the somewhat more distantly related language Javanese, we also see that final $\bar{a}$ in Cam normally corresponds to final $a$ in Malay/Javanese (e.g. 'eye' is matā and 'enter' is tamā in Cam, corresponding to mata and tama in Mal./Jav.).

74. The headings "Sanskrit" vs. "Vernacular" are only rough indicators, for names from both columns are liable to appear both in Sanskrit and in vernacular context. The precise pattern of distribution is not relevant to my argument.

75. On this name, see the contribution by Ferlus (2006) that is equally problematic as his contribution on the name Java discussed above. For a critical remark (although not one that touches on Ferlus' basic Siam argument), see Griffiths \& Lepoutre (forthcoming, n. 23).

76. I define this concept of 'major polity' here - without any pretense that it is valid outside of the scope of my argument - as a polity attested without uncertainty over a period of several centuries both in indigenous written sources and in foreign documents. 
the list above, and whose pair of endonyms corresponds with a pair of names found in the list, ${ }^{77}$ namely the suzerain kingdom of the island of Java.

If we read the epigraphical record of ancient Southeast Asia, and particularly that of Campā and Cambodia, in this light, then we may note how mention of Java in inscriptions of the mainland seems to coincide with known high points in Javanese political power and foreign involvement. I hence propose resolutely to revert to precisely this identification expressed with regard to the Sdok Kak Thom inscription (K. 235) by its translator, Pierre Dupont, ${ }^{78}$ a scholar whom I will have occasion to mention again below.

\section{Who was Satyavarman?}

Out of the four Khmer insciptions mentioned at the outset, two attribute defensive rituals against Javā to Jayavarman II, whose posthumous name was Parameśvara. The accession of this king is supposed to date from 724 Śaka (802 CE), ${ }^{79}$ according to retrospective inscriptions. The two other inscriptions mentioned at the outset attribute the erection of a substantial number of Buddhist images to an undated Satyavarman, and one of these two, the Sab Bak inscription (K. 1158), specifies as reason precisely the same purpose of defense against Javā that we saw specified for Jayavarman II's actions in the inscriptions K. 235 and K. 956. None of the many scholars who have taken note of the historical importance of the Sab Bak inscription have paid any real attention to the name Satyavarman. ${ }^{80}$

Now precisely this name is known as that of a ruler of Campa in the last quarter of the $8^{\text {th }}$ century CE. This is only two decades prior to the presumed

77. The reader will note that this last clause excludes Śrīvijaya.

78. Dupont (in Cœdès \& Dupont 1943-46: 106 n. 1): «Vx-kh. Javā a fait l'objet d'hypothèses diverses, toutes localisées en Indonésie. Le passage par 'Javā' de Jayavarman II doit être rapproché des témoignages arabes sur la sujétion du Cambodge vis-à-vis du mahārāja de Java, et des allusions chames à des expéditions de pillards malais. La suppression de la suzeraineté de Javā est d'ailleurs un des buts énoncés par Jayavarman II, comme on verra plus loin. Le terme Javā désigne très probablement en l'espèce l'île de Java, en plein essor sous les premiers Çailendra (Cf. à ce sujet, G. Cœdès JMBRAS, XIV, III, et Histoire ancienne des États hindouïsés d'E.O., p. 116). Le mot ne peut être séparé de kh.-md. $\check{C} v \hat{a}$ (orthographié $j v \bar{a}$ ), qui s'applique indistinctement à tous les Malais. Il avait peut-être anciennement un sens ethnique, les Javā.»

79. See Majumdar 1943. See also Jacques (1992: 1) who provides no argument against Majumdar in claiming that the year 724 Śaka is that of a special 'imperial' consecration as opposed to an earlier 'normal' royal consecration. This is an utterly ad hoc distinction without any support in the epigraphical record. We may simply have to accept that the date is not reliable, if, as both Jacques and Vickery (forthcoming) are now inclined to do, we identify Jayavarman II with a Jayavarman mentioned in certain Cambodian inscriptions dating from the last decades of the $8^{\text {th }}$ century of our era.

80. Sundberg (2003: 178 n. 28) calls the Kamısten Śrī Satyavarman a "magician", which might suggest that, like the officiants presiding over Jayavarman II's execution of similar stratagems in K. 235 and K. 956, he was a Brahmin, but Sundberg's choice of words is 
accession date of Jayavarman II in 802 CE. Satyavarman was moreover a ruler whose dynasty, according to the inscriptions of Campā cited above (C.38 and C.25), repeatedly had to face attacks from foreign forces. They first struck the north of what is now Vietnam in the year 767 (cf. n. 53 above), then struck Campā in the year 774 CE. This is just one year before the erection of the 'Ligor' inscription in Nakhon Si Thammarat or in Chaiya (in the ancient realm of Panpan, on the East coast of what is now peninsular Thailand), which, whatever its precise historical significance, certainly implies some presence of representatives of archipelago polities so far north: its face A was issued by a Śrivijayan king in 775 CE, and a Śailendra king left a record on face $\mathrm{B}$ of the same stela, most likely at a somewhat later date. ${ }^{81}$ Finally, when naval forces struck Campā again, under Satyavarman's younger brother Indravarman, thirteen years after the attack under Satyavarman in $774 \mathrm{CE}$, they were explicitly identified as being Javanese (javavalasangha). ${ }^{82}$

These correspondences of events and dates can, to my mind, hardly be coincidental. ${ }^{83}$ The fact that nobody ${ }^{84}$ has noticed them may be explained in the first place by the general marginalization of data from Campā history within the greater picture of Southeast Asian historiography, especially outside francophone circles; secondly by the fact that Satyavarman was for

probably just a casual interpretation of the fact that this figure is said to mān siddhi 'possess magical powers'. The suffix 'varman clearly identifies this 'magician' as a member of the ruling estate (kșatriyavarṇa).

81. For a summary of the debate on the interpretation of this inscription's historical significance, and the problem of its provenance, see Jacq-Hergoualc'h (2002: 242-247).

82. I will not enter here into the thorny problems posed by the Ligor inscription's association with a ruler of Śrīvijaya on side A, dated 697 Śaka, but with a Śailendra ruler on the undated and unfinished side B. It must be noted, however, that the curiosity of omitting the name of the weekday observed in the dating formulas of Satyavarman's inscriptions (Griffiths \& Southworth 2007: 367-368 and 2011: 284-285) is shared precisely with their contemporary, the inscription Ligor A; and that face B of this stela shows script which is clearly distinct from the script on face A, and which is clearly identical to the characteristic cursive script of inscriptions of Java of the $9^{\text {th }}$ century.

83. Of significantly less certain pertinence is the partial agreement between the names of Prathivinarendra (sic), ordered to arrange the execution of the kalyannasiddhi againt Java in K. 956 (quoted above) and that of king Prathivindravarman (sic), alias Rudraloka, of whom Satyavarman is said to have been a nephew (see Griffiths \& Southworth 2011: 293-294).

84. Aymonier (1900: 261-270) cites almost in full an 1883 article of Émile Sénart. The latter scholar had spoken of «un personnage peut-être royal du nom de Satyavarman, dont par malheur la date et le rôle nous sont encore complètement inconnus», to which Aymonier added a note (pp. 264-265), explaining that «ce Satyavarman, qui avait jadis consacré des statues du Bouddha, doit être identifié, selon toute vraisemblance, avec le ministre de ce nom qui écrivit l'inscription de Phiméanakas, dans le palais d'Angkor, vers 832 śaka». This information is misleading, for the inscription in question, K. 291, mentions a figure Satyāśraya, of whom it is stated parenthetically that he received the title Mratāñ Khloñ Śrī Satyādhipativarmma (face A, lines 27-28; IC III, p. 199). There is not, as far as I can see, any supporting evidence for the identification proposed by Aymonier. 
more than a century only known to have issued one inscription, the stela of the temple Po Nagar at Nha Trang (C. 38), where the years 696 and 706 Śaka are said to fall within his reign, and where he is credited with repelling a foreign attack and restoring the damage to the mukhalinga at Kauthāra (elsewhere spelled Kuṭhāra), present Nha Trang. This track record seems to have been insufficiently glorious for scholars of ancient Cambodia to consider associating him with the erection(s) of nine and/or ten Buddhist images recorded in the Vat Sithor and Sab Bak inscriptions.

But discoveries of two exceptional Sanskrit inscriptions in recent years have significantly enriched our picture of this Satyavarman. While the lower and upper date limits of his reign in Campā are still unaltered, and we have learned no more of his encounters with foreign forces, we can now confidently credit this Satyavarman with the foundation of the important temple complex of Hoà Lai, near Phan Rang, and more generally with the development of Pāṇụranga as a major bastion of Campā culture. ${ }^{85}$ Indeed Satyavarman's power base seems to have been only here, in the far south of Campā, and he has left no traces elsewhere in Campā territory. Now Pierre Dupont, in a remarkably foresighted paper published in 1949, had already noted several striking correspondences between Satyavarman's dynasty and pre-angkorian Khmer rulers. Chief among these is the custom of using posthumous names. ${ }^{86}$ Other scholars, such as Stern (1942) and Boisselier (1956), have noticed stylistic correspondences between art of $7^{\text {th }}$ century CE Cambodia and contemporary Campā art at Mỹ Sơn, far to the north of Pāṇụrañga, under Prakāśadharman-Vikrāntavarman, who was of Khmer descent. And they have noted the same between the mentioned temple of Hoà Lai and the Prasat Damrei Krap on the Phnom Kulen (cf. Griffiths \& Southworth 2011: 272-275). Ornamental and architectural connections have also been pointed out between temples of Pāṇḍrañga (such as Hoà Lai), monuments in the realm of former Panpan in peninsular Thailand, the area of provenance of the 'Ligor' inscription mentioned above, and the monumental art of Central Java (cf. Jacq-Hergoualc'h 2001).

In the light of all the positive evidence for intensive political contact, even extending to the migration of a ruler (Prakāśadharman) from ancient pre-angkorian Cambodia to take up power in Campā; in the light of long recognized artistic connections between insular and mainland Southeast Asia in general, as well as specific connections around the turn of the $9^{\text {th }}$ century $\mathrm{CE}$; in the light of the fact that the political situation in pre-angkorian

85. See the articles by Griffiths \& Southworth of 2007 and 2011.

86. In his article devoted to posthumous names of Khmer rulers, Jacques (2001: 195-196) expresses some doubt as to the real existence of such a tradition in these Campā inscriptions. The issue is indeed somewhat uncertain, but I see no specific reasons not to assume, with Dupont, that some posthumous names were in use in early Southern Campā. 
Cambodia is very uncertain precisely in the period of Satyavarman's reign in Southern Campā; in the light of the positive evidence that we have for attacks from Java and for a Buddhist ruler from the archipelago showing his influence halfway up the Malay peninsula in precisely this same period; in the light of all these factors, it appears to me not so far-fetched at all to propose that it was the Satyavarman of Pāndurañga in Campā who undertook the erection of the Buddhalokeśvara images on the Abhayagiri, retrospectively recorded by the two Khmer inscriptions of Vat Sithor and Sab Bak, or at least to propose that he was a figure of sufficient grandeur to have left a memory even beyond the boundaries of Campā and could hence have become the object of attribution of retrospective legends in ancient Cambodia.

If the former, more audacious hypothesis is accepted, we may become one step more speculative and ponder the possibility that the Abhayagiri was situated not in Khmer territory, nor in Campā nor on the Malay Peninsula, but can be identified with the Ratu Baka hillock in Central Java, which housed the Abhayagiri monastery founded by a Śailendra king in 714 Śaka (782 CE), in which case we would have to presume that the Ratu Baku hillock was already famous as Abhayagiri before a monastery was founded on it in collaboration with Sinhalese monks of the eponymous Abhayagirivihāra in Sri Lanka. ${ }^{87}$ Satyavarman would have made the long pilgrimage to and made large-scale foundations at that sacred Buddhist site ${ }^{88}$ not so much for religious reasons - in fact from the Campā record Satyavarman is exclusively associated with Brahmanical foundations — but to engage in diplomacy with the expansive Sailendra rulers, to persuade them to leave mainland Southeast Asia in peace. ${ }^{89}$ But I must frankly admit that the argument for extending the hypothesis this far is entirely circum-stantial, and that one can easily imagine multiple Abhayagiris in more than one part of Southeast Asia — southern Cambodia, southern Vietnam, peninsular Thailand, besides the one on Java — so I will conclude by summarizing my main claims. These are, first, that the Khmer inscriptions refer to the island

87. On this point, see the convincing arguments made by Sundberg (2004) for identification of a structure on the Ratu Baka plateau as Abhayagirivihāra, with evidence of contacts with a Sri Lankan eponym. On the site in general, see Degroot (2006).

88. Sundberg (2003: 178): "Lokesh Chandra (...) infers the existence of a large statue of Avalokiteśvara on the Ratu Baka from his study of the Abhayagirivihāra inscription, noting that it would complement the statues of Tārā and Mañjuśrī which were known to be already positioned on the plain."

89. Recall the two stanzas from the Campā inscription C. 149 which have a possibly Buddhist aristocrat undertake no less than two siddhayātrā missions from his country to Yavadvipapura. Whatever this may mean precisely, the connection with siddhi in relationship to Yavadvīpa, which must mean Java, would seem to offer a tantalizing parallel with Satyavarman. 
of Java when they use the term Javā and, second, that the epigraphical record of Satyavarman and his immediate successors in Southern Campā is likely to hold important clues not only for the history of Campā, but equally for international political relations between the Khmer, Cam and Javanese polities in the late $8^{\text {th }}$ and early $9^{\text {th }}$ century of our era. This second point holds especially for a re-appraisal of the early days of Angkor which have thus far always been associated with the name Jayavarman II, ${ }^{90}$ despite the fact that we entirely lack contemporary evidence for his role, because we now have a source - likewise retrospective - where part of the episodes traditionally associated with this Jayavarman II are attributed to a Satyavarman.

\section{REFERENCES}

Ang Chouléan, 1998, "Collective memory in ancient Cambodia with reference to Jayavarman II", in: M.J. Klokke \& T. de Bruijn (eds.), Southeast Asian Archaeology 1996, Hull: Centre for Southeast Asian Studies, 117-122.

Aymonier, Étienne, 1891, «Première étude sur les inscriptions tchames», Journal Asiatique, series $8,17,5-86$.

_, 1900, Le Cambodge. [Tome I:] Le royaume actuel. Paris: Ernest Leroux.

_, 1911, "L'inscription čame de Po Sạ̣», Bulletin de la commission archéologique de l'Indochine (1911), 13-19.

Barret Jones, Antoinette M., 1984, Early Tenth Century Java from the Inscriptions. A study of the economic, social and administrative conditions in the first quarter of the century. Dordrecht: Foris Publications.

Barth, Auguste, 1885, Inscriptions sanscrites du Cambodge. Notices et extraits de la Bibliothèque nationale et autres bibliothèques. Tome XXVII, $1^{\text {re }}$ partie, $1^{\text {er }}$ fascicule (Paris: Imprimerie nationale), 1-180.

Bergaigne, Abel, 1893, Inscriptions sanscrites de Campā et du Cambodge. Tiré des notices et extraits de la Bibliothèque nationale et autres bibliothèques. Tome XXVII, $1^{\text {re }}$ partie (Paris: Imprimerie nationale), $1[=181]-448[=628]$. [I cite the page numbering of the offprint.]

Bernet Kempers, A.J., 1967, "De lotgevallen van een tekstregel", Spiegel der Historie 2.6, 468-476.

Bhattacharya, Kamaleswar, 1991, Recherches sur le vocabulaire des inscriptions sanskrites du Cambodge. Paris: École française d'Extrême-Orient.

Boechari, 1976, "Some considerations of the problem of the shift of Matarām's center of government from Central to East Java in the $10^{\text {th }}$ century A.D.", Berita Pusat Penelitian Purbakala dan Peninggalan Nasional/Bulletin of the Research Centre of Archeology, 10.

—, 1979, “An Old Malay Inscription of Śrīwijaya at Palas Pasemah (South Lampung)”, in Pra Seminar Penelitian Śriwijaya, Jakarta: Pusat Penelitian Purbakala dan Peninggalan Nasional, 18-40.

-, 1986, "New Investigations on the Kedukan Bukit Inscription”, in Untuk Bapak Guru. Persembahan para murid untuk memperingati usia genap 80 tahun Prof. Dr. A.J. Bernet Kempers, Jakarta: Pusat Penelitian Arkeologi Nasional, Departemen Pendidikan dan Kebudayaan, 33-56.

90. Cf., among many other studies, Jacques (1972) and Ang Chouléan (1998). 
-, 2012, Melacak Sejarah Kuno Indonesia Lewat Prasasti. Tracing Ancient Indonesian History through Inscriptions. Jakarta: Kepustakaan Populer Gramedia.

Boisselier, Jean, 1956, «Art du Champa et du Cambodge préangkorien. La date de Mi-Sơn EI», Artibus Asiae 19.3/4, 197-212.

Bourdonneau, Éric, 2003, «Culturalisme et historiographie du Cambodge ancien : à propos de la hiérarchisation des sources de l'histoire khmère», Moussons 7, 39-70.

—, 2007, «Réhabiliter le Funan. Óc Eo ou la première Angkor», Bulletin de l'École française d'Extrême-Orient 94, 111-158.

-, 2011a, «Nouvelles recherches sur Koh Ker (Chok Gargyar). Jayavarman IV et la maîtrise des mondes », Monuments et mémoires de la Fondation Eugène Piot 90, 93-141.

—, 2011b, «La fondation du culte du devarāja. Danse, sacrifice et royauté au Prasat Thom de Koh Ker», Comptes rendus de l'Académie des inscriptions et belles-lettres 2011, III (juillet-octobre), 1343-1382.

Brandes, J.L.A., 1913, Oud-Javaansche Oorkonden. Nagelaten transscripties van wijlen Dr. J.L.A. Brandes. Uitgegeven door Dr. N.J. Krom. [Verhandelingen van het Bataviaasch Genootschap voor Kunsten en Wetenschappen, 60.] Batavia, 's-Hage: Albrecht \& Co., M. Nijhoff.

de Casparis, J.G., 1956, Selected Inscriptions from the $7^{\text {th }}$ to the $9^{\text {th }}$ Century A.D. [Prasasti Indonesia II.] Bandung: Masa Baru.

-, 1995, "Peranan Adityawarman, Putera Melayu di Asia Tenggara", in Ismail Hussein et al. (eds.), Persidangan Antarbangsa Tamadun Melayu III, Kuala Lumpur, Kementerian Kebudayaan dan Pelancongan Malaysia, 918-943.

Chhabra, B.Ch., 1948, "Siddhayātrā", Indian Culture 14, 201-204.

-, 1965, Expansion of Indo-Aryan Culture during Pallava Rule (as evidenced by inscriptions). Delhi: Munshi Ram Manohar Lal.

Chirapat Prapandvidya, 1990, "The Sab Bāk Inscription. Evidence of an Early Vajrayāna Buddhist Presence in Thailand", Journal of the Siam Society 78, 11-14.

Cœdès, George, 1924, Recueil des inscriptions du Siam. Première partie : inscriptions de Sukhothaya. Bangkok: Bangkok Times Press.

-, 1930, «Les inscriptions malaises de Çrīvijaya», Bulletin de l'École française d'ExtrêmeOrient 30, 29-80.

—, 1937-66, Inscriptions du Cambodge. 8 vols. Hanoi [vol. I], Paris: Imprimerie d'ExtrêmeOrient [vol. I], EFEO.

—, 1941, «La stele du Práh Khằn d'Añkor», Bulletin de l'École française d'Extrême-Orient 41, 255-302.

-, 1968, The Indianized States of Southeast Asia. Edited by Walter F. Vella. Translated by Sue Brown Cowing. Honolulu: University of Hawaii Press.

Cœedès, George \& Pierre Dupont, 1943-46, «Les stèles de Sdǒk Kăk Thoṃ, Phnoṃ Sandak et Prạ Vihār», Bulletin de l'Ecole française d'Extrême-Orient, 43.1, 56-154.

Cœdès, George \& Henri Parmentier, 1923, Listes générales des inscriptions et des monuments du Champa et du Cambodge. Hanoi: Imprimerie d'Extrême-Orient.

Damais, Louis-Charles, 1952, «Etudes d'épigraphie indonésienne. III : Liste des principales inscriptions datées de l'Indonésie», Bulletin de l'École française d'Extrême-Orient 46.1, $1-105$.

—, 1957, «Bibliographie. Prof. Dr Poerbatjaraka: Riwajat Indonesia, djilid I», Bulletin de l'École française d'Extrême-Orient 48.2, 607-649.

—, 1964, «Etudes sino-indonésiénnes. III. La transcription chinoise 訶 陵 ho-ling comme désignation de Java», Bulletin de l'École française d'Extrême-Orient 52.1, 93-141.

—, 1970, Répertoire onomastique de l'épigraphie javanaise jusqu'à Pu Siṇdok Śrī Iśānawikrama Dharmmottungadewa. Paris: Ecole française d'Extrême-Orient. 
Deeg, Max, 2005, Das Gaoseng-Faxian-Zhuan als religionsgeschichtliche Quelle. Der älteste Bericht eines chinesischen buddhistischen Pilgermönchs über seine Reise nach Indien mit Übersetzung des Textes. Wiesbaden: Harrassowitz.

Degroot, Véronique, 2006, "The Archaeological Remains of Ratu Boko: from Sri Lankan Buddhism to Hinduism", Indonesia and the Malay World vol. 34, issue 98, 55-74.

Dupont, Pierre, 1949, «Tchen-la et Panduranga : Le sud indochinois aux VIe et VII ${ }^{\mathrm{e}}$ siècles », Bulletin de la Société des Études Indochinoises - nouvelle série 24 (no. 1), 9-25.

Estève, Julia, 2009, Étude critique des phénomènes de syncrétisme religieux dans le cambodge angkorien. Thèse de doctorat. Paris: École Pratique des Hautes Études, Section des sciences religieuses.

Ferlus, Michel, 2005, «L'intérêt linguistique des transcriptions chinoises concernant le Cambodge ancien (Fou-nan et Tchen-la)», paper presented at the Vingtièmes Journées de Linguistique de l'Asie Orientale, CRLAO (CNRS-EHESS), 22-23 June 2005.

—, 2006, «Sur l'origine de la dénomination 'Siam'», Aséanie 18, 107-117.

—, 2010, «Localisation, identité et origine du Javā de Jayavarman II», Aséanie 26, 65-81.

Gerini, G.E., 1905, "The Nagarakretagama List of Countries on the Indo Chinese Mainland (circâ 1380 A.D.)", Journal of the Royal Asiatic Society, July 1905, 485-511.

Gerschheimer, Gerdi, 2003-04, «Le Corpus des inscriptions khmères», Bulletin de l'École française d'Extrême-Orient 90-91, 478-482.

Griffiths, Arlo, Amandine Lepoutre, William A. Southworth \& Thành Phần, 2012a, «Épigraphie du Campā 2009-2010 : prospection sur le terrain, production d'estampages, supplément à l'inventaire», Bulletin de l'École française d'Extrême-Orient 95-96 (2008-2009, published 2012), 435-497.

-, 2012b, The Inscriptions of Campā in the Museum of Cham Sculpture at Đà Nã̃ng. Hanoi: EFEO and Ho Chi Minh City: Center for Vietnamese and Southeast Asian Studies, VNUHCM Publishing House.

Griffiths, Arlo \& Amandine Lepoutre, forthcoming, "Campā Epigraphical Data on Polities and People of Ancient Myanmar", Journal of Burma Studies 17.2 (2013).

Griffiths, Arlo \& William A. Southworth, 2007, «La stèle d'installation de Śrī Satyadeveśvara : une nouvelle inscription du Campā trouvée à Phước Thiện», Journal Asiatique 295, 349-381.

—, 2011, «La stèle d'installation de Śrī Ādideveśvara : une nouvelle inscription de Satyavarman trouvée dans le temple de Hoà Lai et son importance pour l'histoire du Pāṇụunanga », Journal Asiatique 299, 271-317.

Griswold, A.B. \& Prasert ṇa Nagara, 1971, "The Inscription of King Rāma Gaṃhèn of Sukhodaya (1292 A.D.). [Epigraphic and Historical Sudies No. 9]", Journal of the Siam Society 59.2, 179-228.

Hadi Sidomulyo, 2010, "From Kuța Rāja to Singhasāri. Towards a Revision of the Dynastic History of $13^{\text {th }}$ Century Java", Archipel 80, 77-138.

Hoshino, Tatsuo, 1986, Pour une histoire médiévale du moyen Mékong. Bangkok: Editions Duang Kamol.

—, 2002, "Wen Dan and its Neighbours: the Central Mekong Valley in the Seventh and Eighth Centuries", in Mayoury Ngaosrivathana \& K. Breazeale (eds.), Breaking New Ground in Lao History: Essays on the Seventh to Twentieth Centuries, Chiang Mai: Silkworm Books, 25-72.

Huber, Edouard, 1911, «Études indochinoises VIII-XII», Bulletin de l'École française d'Extrême-Orient 11, 259-311.

Jacq-Hergoualc’h, Michel, 2001, «A propos de transferts de formes communs au Campā et au Panpan (péninsule Malaise) au IX ${ }^{\mathrm{e}}$ siècle», Arts Asiatiques 56, 45-60. 
—, 2002, The Malay Peninsula. Crossroads of the Maritime Silk Road (100 BC-1300 AD). Leiden: Brill.

Jacques, Claude, 1972, «Études d'épigraphie cambodgienne, VIII. La carrière de Jayavarman II», Bulletin de l'École française d'Extrême-Orient 69, 205-220.

-, 1992, "On Jayavarman II, the founder of the Khmer empire", in Southeast Asian Archaeology 1990, Hull: Centre for Southeast Asian Studies, 1-5.

—, 2001, «Les noms posthumes des rois dans l'ancien Cambodge», in M.J. Klokke \& K.R. van Kooij (eds.), Fruits of Inspiration: Studies in Honour of Prof. J.G. de Casparis, Groningen: Egbert Forsten, 191-198.

—, 2005, «Deux problèmes posés par l'inscription de la stèle de Prạ̣ Khan K. 908 », Aséanie 15, 11-32.

Jenner, Phillip N., 2009a, A Dictionary of pre-Angkorian Khmer. [Pacific Linguistics, 597.] Canberra: Pacific Linguistics.

—, 2009b, A Dictionary of Angkorian Khmer. [Pacific Linguistics, 598.] Canberra: Pacific Linguistics.

Kern, H., 1885, "Sanskrit-inscriptie van Java, van den jare 654 Çaka (A. D. 732)", Bijdragen tot de Taal-, Land- en Volkenkunde 34, 125-138 [Verspreide Geschriften VII (1917), VII, 115-128].

—, 1917, Verspreide Geschriften. Zevende deel: Inscripties van den Indischen archipel, slot; De Nāgarakṛtāgama, eerste gedeelte. 's-Gravenhage: Martinus Nijhoff.

Khyac Sinh [Chit Thein], 1965, Rheh horịh mvan kyok cā poìh khyup [Collected Ancient Mon Inscriptions]. Yangon: Department of Archaeology.

Krom, N.J., 1914, "Remen”, Journal of the Royal Asiatic Society, Oct. 1914, 1069.

-, 1931, Hindoe-Javaansche Geschiedenis. Tweede, herziene druk. 's-Gravenhage: Martinus Nijhoff.

Kuntara Wiryamartana, I., 1990, Arjunawiwāha. Transformasi teks Jawa Kuna lewat tanggapan dan penciptaan di lingkungan sastra Jawa. Yogyakarta: Duta Wacana University Press.

-, 1993, "The scriptoria in the Merbabu-Merapi area", Bijdragen tot de Taal-, Land- en Volkenkunde 149.3 (Manuscripts of Indonesia), 503-509.

Laffan, Michael, 2009, "Finding Java: Muslim nomenclature of insular Southeast Asia from Srivijaya to Snouck Hurgronje", in Eric Tagliacozzo (ed.), Southeast Asia and the Middle East: Islam, movement, and the longue durée, Stanford, Calif.: Stanford University Press, $17-64$.

Lefeber, Rosalind \& Robert P. Goldman, 1994, The Rāmāyana of Vālmīki. An Epic of Ancient India. Vol. IV: Kișkindhākānda. Princeton: Princeton University Press.

Lepoutre, Amandine, forthcoming, «Les inscriptions du temple de Svayamutpanna: contribution à l'histoire des relations entre les pouvoirs cam et khmer (de la fin du XII ${ }^{\mathrm{e}}$ siècle au début du XIII ${ }^{\mathrm{e}}$ siècle)», Journal Asiatique 300.2 (2012).

Luce, Gordon H., 2003-04, Old Burma-Early Pagán. 3 vols. [Artibus Asiae, Supplementum, vol. 25.] New York: J.J. Augustin.

Mahdi, Waruno, 2005, "Old Malay", in A. Adelaar \& N.P. Himmelmann (eds.), The Austronesian Languages of Asia and Madagascar, Routledge: London \& New York, 182-201.

—, 2008, "Yavadvipa and the Merapi Volcano in West Sumatra", Archipel 75, 111-143.

Majumdar, R.C., 1927, Champā: History and Culture of an Indian Colonial Kingdom in the Far East $2^{\text {nd }}-16^{\text {th }}$ Century A. D. New Delhi: Gyan Publishing House, 1985 [reprint].

-, 1943, "The Date of Accession of Jayavarman II", Journal of the Greater India Society $10,52-55$. 
Manguin, Pierre-Yves \& Agustijanto Indrajaya, 2011, "The Batujaya Site: New Evidence of Early Indian Influence in West Java", in P.-Y. Manguin, A. Mani \& Geoff Wade (eds.), Early Interactions between South and Southeast Asia: Reflections on Cross-Cultural Exchange, Singapore: ISEAS Publishing, 113-136.

Mertens, Annemarie, 2000, "Beobachtungen zur Herrschaftslegitimation im Ankkor-Reich. Die buddhistisch orientierte Vat-Sithor-Inschrift von Jayavarman V", in C. Chojnacki, J.U. Hartmann \& V.M. Tschannerl (eds.), Vividharatnakarandaka: Festgabe für Adelheid Mette, Swisttal-Odendorf: Indica et Tibetica Verlag, 395-411.

Michel, Wesley, 2011, "Poetic Conventions as Opposed to Conventional Poetry? A Place for kavisamayādi in Comparative Kāvya/Kakawin Studies", in A. Acri, H. Creese \& A. Griffiths (eds.), From Lañka Eastwards. The Ràmāyaña in the Literature and Visual Arts of Indonesia, Leiden: KITLV Press, 11-23.

Nilakanta Sastri, K.A., 1937, "Siddhayātrā", Journal of the Greater Indian Society 4, $128-136$.

—, 1948-49, "Siddhayatra Again", Indian Culture 15 (B.M. Barua Commemoration Volume), 52.

Noorduyn, J., 1982, “Bujangga Manik's journeys through Java. Topographical data from an old Sundanese source", Bijdragen tot de Taal-, Land- en Volkenkunde 138, 413-442.

Pigeaud, Theodoor Gautier Thomas, 1960-63, Java in the 14th century. A study in cultural history. 5 vols. [Koninklijk Instituut voor Taal-, Land- en Volkenkunde. Translation Series, 4.] The Hague: Martinus Nijhoff.

Poerbatjaraka, R. Ng., 1922, "De inscriptie van het Mahākșobhya-beeld te Simpang (Soerabaya)", Bijdragen tot de Taal-, Land-en Volkenkunde 78, 426-462.

Pollock, Sheldon, 2006, The Language of the Gods in the World of Men: Sanskrit, culture, and power in premodern India. Berkeley and Los Angeles: University of California Press.

Robson, Stuart, 1995, Deśawarnana (Nāgarakrtāgama) by Mpu Prapañca. Leiden: KITLV Press.

-, 1997, "Thailand in an Old Javanese source", Bijdragen tot de Taal-, Land-en Volkenkunde 153, 431-435.

Sak-Humphry, Chhany \& Philip N. Jenner, 2005, The Sdok Kak Thom Inscription (K. 235). With a Grammatical Analysis of the Old Khmer Text [publication signed by Chh. S.-H., "with the assistance of Ph. N. J."]. Phnom Penh: Buddhist Institute.

Sarkar, Himansu Bhusan, 1971-72 Corpus of the Inscriptions of Java (up to 928 A.D.). 2 vols. Calcutta: Firma K.L. Mukopadhyay.

Sharrock, Peter, 2009, "Kīrtipandita and the Tantras", Udaya: Journal of Khmer Studies 10, 203-237.

Shorto, H.L., 1971, A Dictionary of the Mon Inscriptions from the Sixth to the Sixteenth Centuries. London: Oxford University Press.

Skilling, Peter, 2004, "Random Jottings on Srīghana: An Epithet of the Buddha", Annual Report of the International Research Institute for Advanced Buddhology (Soka University) 7, 147-158.

Soutif, Dominique, 2009, Organisation religieuse et profane du temple khmer du VII au XIII siècle. 3 vols. Thèse de doctorat, Universite Sorbonne Nouvelle - Paris 3.

Stern, Philippe, 1942, L'art du Champa (ancien Annam) et son évolution. Toulouse and Paris: Les Frères Douladoure and Adrien-Maisonneuve.

Stutterheim, W.F., 1927, "Een belangrijke oorkonde uit de Kĕḍoe", Tijdschrift voor Indische Taal-, Land- en Volkenkunde 67, 172-215.

-, 1935, "Epigraphica I-V”, Tijdschrift voor Indische Taal-, Land- en Volkenkunde 75, 420-467. 
-, 1939, "Note on cultural relations between South-India and Java", Tijdschrift voor Indische Taal-, Land- en Volkenkunde 79, 73-84.

Sundberg, Jeffrey Roger, 2003, "A Buddhist mantra recovered from the Ratu Baka plateau. A preliminary study of its implications for Śailendra-era Java", Bijdragen tot de Taal-, Land- en Volkenkunde 159, 163-188.

—, 2004, "The wilderness monks of the Abhayagirivihara and the origins of Sino-Javanese esoteric Buddhism", Bijdragen tot de Taal-, Land- en Volkenkunde 160, 95-123.

—, 2009, "The State of Matarām: A review of recent efforts to clarify its history", Appendix A, pp. 329-362, in Mark Long, Canḍi Mendut: Womb of the Tathägata, New Delhi: Aditya Prakashan.

Terwiel, B.J., 2011, “Using Ockham's Razor with Respect to the Ram Khamhaeng Controversy," in Volker Grabowsky (ed.), Southeast Asian Historiography: Unravelling the Myths, Bangkok: River Books, 42-51.

Titi Surti Nastiti, 2003, Pasar di Jawa pada Masa Matarām Kuna, Abad VIII-XI Masehi. Jakarta: Pustaka Jaya.

Titi Surti Nastiti, Dyah Wijaya Dewi \& Richadiana Kartakusuma, 1982, Tiga Prasasti dari Masa Balitung. Jakarta: Proyek Penelitian Purbakala, Departemen P \& K. Pusat Penelitian Arkeologi Nasional.

Vickery, Michael, 1992, "Evidence for Prehistoric Austronesian-Khmer Contact and Linguistic Borrowing", Mon-Khmer Studies 21, 185-189.

-, 1998, Society, Economics, and Politics in Pre-Angkor Cambodia. The $7^{\text {th }} 8^{\text {th }}$ Centuries. Tokyo: The Centre for East Asian Cultural Studies for Unesco.

-, 2001, "Resolving the Chronology and History of $9^{\text {th }}$ Century Cambodia", Siksacakr 3, $17-23$.

—, 2003-04, "Funan Reviewed: Deconstructing the Ancients", Bulletin de l'École française d'Extrême-Orient 90-91, 101-143.

-, 2004, Cambodia and Its Neighbors in the 15th Century. Singapore: Asia Research Institute, Working Paper no. 27.

-, forthcoming, "A legend concerning Jayavarman II", paper first presented at EFEO Paris in September 2004, since revised; subject to further revision.

Wisseman Christie, Jan, 1999, "Asian Trade between the Tenth and Thirteenth Centuries and Its Impact on the States of Java and Bali", in H.P. Ray (ed.), Archaeology of Seafaring: The Indian Ocean in the Ancient Period, Delhi: Pragati Publications, 221-270.

Wolters, O.W., 1973, "Jayavarman II's Military Power: The Territorial Foundation of the Angkor Empire", Journal of the Royal Asiatic Society of Great Britain and Ireland 1973, 21-30.

—, 2008, Early Southeast Asia: Selected Essays. Edited by Craig J. Reynolds. Ithaca, New York: Southeast Asia Program Publications, Cornell University.

Woodward, Hiram W. Jr., 1994-95, "The Jayabuddhamahānātha Images of Cambodia", Journal of the Walters Art Gallery 52-53, 105-11.

-, 2005, The Art And Architecture of Thailand from Prehistoric Times through the Thirteenth Century. Second Edition. Leiden-Boston: Brill.

-, 2011, "Dvaravati, Si Thep and Wendan", Bulletin of the Indo-Pacific Prehistory Association 30 (2010), 87-97.

Zoetmulder, P.J., 1976, review of Sarkar 1971-72, Bijdragen tot de Taal-, Land-en Volkenkunde 132, 188-192. 